\title{
Imperatyw opieki paliatywnej w medycynie weterynaryjnej
}

\author{
Krzysztof Kuśnierz
}

(Uniwersytet im. Adama Mickiewicza w Poznaniu, kristofka@vp.pl)

\section{Homo animalis}

Tytułem wprowadzenia do problematyki opiekuńczo-leczniczej względem zwierząt udomowionych i hodowlanych oraz towarzyszących jej kwestii moralnych i prawnych chciałbym tutaj zarysować

- stan dotychczasowego rozwoju opiekuńczości człowieka wobec innych zwierząt (na wybranych przykładach takich praktyk, podejmowanych na świecie),

- podstawy aksjologiczne i uzasadnienia normatywne dla tego rodzaju opiekuńczości, które w sposób nieunikniony związane są z ludzką odpowiedzialnością, zdolnością do empatii, troski i wreszcie $\mathrm{z}$ racjonalnością, rozumnością i określonymi praktykami o charakterze uregulowanym i zinstytucjonalizowanym (np. medycyną weterynaryjną), które nadają człowiekowi przewagę w relacji do innych istot żywych . Chciałbym tę przewagę rozumieć jako źródło pozytywnych działań, mających na celu poprawę zwierzęcego losu. Jeśli nawet podtrzymuje ona dyskutowany współcześnie antropocentryzm i paternalizm, to zmienia ich oblicze, wypierając eksploatacyjne nastawienie człowieka do zwierząt na rzecz troski i odpowiedzialności za ich położenie.

- dyskusje wśród profesjonalistów, działaczy na rzecz praw zwierząt żyjących w zależności od homo sapiens, lekarzy weterynarii, a także laików zainteresowanych kondycją i dobrostanem zwierząt. Dyskusje toczą się wokół wspomnianych praktyk, ich zasadności i skuteczności, stopniowo poprawiając relacje współczesnego człowieka ze zwierzętami, a co najważniejsze, położenie i kondycję tych ostatnich.

Aby ograniczyć refleksję prowadzoną według powyższych założeń jakimś rozsądnym horyzontem, sięgnę tylko do wybranych tekstów autorstwa przedstawicieli ruchu na rzecz praw zwierząt, lekarzy weterynarii, filozofów i etyków, którzy postawili interesujące mnie pytania w sposób pionierski albo też udzielili na nie najbardziej znaczące odpowiedzi.

Tylko w 2001 roku w Północnej Ameryce i Europie w celu wykarmienia ludzi, wyhodowano i zabito ok. 17 miliardów zwierząt lądowych. Od 50 do 100 milionów innych zwierząt wykorzystano $\mathrm{i}$ uśmiercono $\mathrm{w}$ laboratoriach, podczas gdy 
kolejnych 30 milionów pozbawiono życia na fermach futrzarskich (Gaverick 2006, s. 13).

Astronomiczne liczby przywoływane w tym raporcie wskazują jednoznacznie na powszechną orientację człowieka w pierwszym rzędzie na użytkowy aspekt zwierzęcego życia: niezachwianym priorytetem ludzkości pozostaje czerpanie korzyści ze zwierząt. Priorytet ten przesłania i zaciera wrażliwość na kondycję, a zwłaszcza cierpienie istot pozostających w stałej i całkowitej zależności od interesów, praktyk, stylu życia i technicznej organizacji świata życia homo sapiens. Dodatkowo, nadal mający przewagę w kulturze ludzkiej i postrzeganiu „reszty” świata ożywionego szowinizm gatunkowy (speciesism) legitymizuje zarówno te wysokie liczby jak i wskazane praktyki. Szowinizm gatunkowy dotyczy także tych spośród nas, którzy koegzystują z innym, zwierzęcym przedstawicielem świata ożywionego na sposób towarzyski, bowiem zazwyczaj ten przykład wrażliwości zawęża się selektywnie do tego zwierzęcia, z którym obcujemy bezpośrednio i rozwijamy wobec niego empatię i sympatię, nierzadko postrzegając je w sposób antropomorficzny i przypisując właściwości (również psychiczne, emocjonalne, dotyczące inteligencji itd.) ludzkie. Takie postawy często bywają sprzeczne $\mathrm{z}$ naszymi nawykami dietetycznymi.. Z łatwością - tj. bez niezbędnej tutaj refleksji etycznej $\mathrm{i}$ społecznej, wynikającej $\mathrm{z}$ bycia współmieszkańcami świata istot żywych, z poczucia solidarności z gatunkami pozaludzkimi, a przede wszystkim z poczucia odpowiedzialności za kondycję, losy, samopoczucie, jakość życia, zdrowie, chorobę, narodziny, starzenie się i umieranie zwierząt oswojonych, udomowionych, hodowanych lub eksploatowanych przez człowieka z jego woli, ale za to bez woli zwierząt przechodzimy od sympatii żywionej wobec zwierzęcych współlokatorów do konsumpcji innych gatunków traktowanych jako surowiec, element diety, zestaw produktów do dalszej obróbki i przetwórstwa na skalę przemysłową lub domową. Kwestia relacji człowieka z przedstawicielami innych gatunków, a także kwestia zmiany tej relacji jest wobec tego efektem licznych uwarunkowań socjo-ekologicznych, w tym zwłaszcza zwyczajów i nawyków, dających podstawy tzw. normom kulturowym. Relacje te są regulowane także przez rozmaite etyki, zarówno religijne, jak i poza-religijne (świeckie); tych powszechnie dostępnych i znanych regulacji nie będę tutaj omawiać. Dla odmiany, przywołam jeden z najstarszych manifestów filozoficznych na rzecz eliminacji udziału zwierząt $\mathrm{w}$ ludzkiej diecie autorstwa Henry'ego Davida Thoreau (1817-1862):

Ciężko jest zdobyć i ugotować tak proste i czyste pożywienie, aby nie raziło uczuć estetycznych. Myślę, że powinno je się karmić jednocześnie z ciałem, a zatem wszyscy powinni siadać przy tym samym stole. Chyba to możliwe do przeprowadzenia (...) Czyż fakt, że człowiek jest zwierzęciem mięsożernym, nie przynosi mu ujmy? Wszak w wielkiej mierze żyje polując na inne zwierzęta; 
przykry sposób, o czym przekona się każdy, kto zacznie łapać w sidła króliki albo zarzynać jagnięta. Przeto ten zostanie uznany za dobroczyńcę ludzkości, kto nauczy człowieka ograniczenia się do bardziej niewinnego i zdrowego pożywienia. Niezależnie od tego, co sam praktykuję, nie mam wątpliwości, że przeznaczeniem gatunku ludzkiego $\mathrm{w}$ miarę stopniowego postępu jest po części skończyć z jedzeniem zwierząt. To niechybnie nastąpi, podobnie jak u dzikich plemion skończono $\mathrm{z}$ jedzeniem siebie nawzajem wskutek zetknięcia się $\mathrm{z}$ ludźmi bardziej cywilizowanymi (Thoreau 1991, s. 263-264).

Tym z nas, którzy (dla nader różnorodnych racji i uzasadnień) nie zrezygnowali ze spożywania mięsa ani nawet nie myślą o ograniczeniu jego ilości w swej diecie nie sposób całkowicie odmówić empatycznego podejścia do zwierząt - i to nie tylko tych udomowionych czy oswojonych. Nawet jeśli podejście empatyczne wiąże się nie tylko ze współodczuwaniem i zdolnością do udzielania się człowiekowi i odwzajemniania przezeń na poziomie emocjonalnym i afektywnym stanów, w jakich znajdują się inne żywe istoty (a nawet wyobrażenia tych istot $\mathrm{w}$ dziełach plastycznych, literackich, filmowych itd.), lecz także z przypisywaniem innym własnych doznań, odczuć i stanów. Empatia pozostaje najważniejszym zalążkiem relacji $\mathrm{z}$ innymi istotami, nieznającymi ludzkich form auto-ekspresji. To właśnie ona uruchamia procesy poznawcze u człowieka, stając się źródłem informacji i danych, służących za podstawę refleksji i możliwie właściwych decyzji w stosunku do istot spoza gatunku ludzkiego .

Brak wzajemnej komunikacji językowo-symbolicznej pomiędzy człowiekiem a przedstawicielami innych gatunków zwierząt sprawia, że wszelka relacja z nimi jest możliwa tylko dzięki obserwacji, rozpoznawaniu i rozumieniu zachowań zwierząt (zoopsychologia, etologia, bionomia, etc.).; Dopiero na podstawie obserwacji można określić, jakie żywotne potrzeby mają osobniki należące do poszczególnych gatunków lub osobniki, których zachowanie zmieniło się (zwykle nieodwracalnie) pod wpływem obcowania z człowiekiem lub przebywania w sztucznych warunkach, nieprzypominających w niczym naturalnego ekosystemu i pierwotnego środowiska życia. Tylko w szczególnych warunkach, w pełni zależnych od człowieka, możliwe jest wytworzenie organicznej więzi pomiędzy opiekunem a podopiecznym. Być może jej siła polega na tym właśnie, że wyraża się ona poprzez funkcjonalnoeskpresywny charakter komunikacji międzygatunkowej, który skutecznie chroni ją przed zupełnym skonwencjonalizowaniem. Komunikacja pozawerbalna, zwłaszcza język ciała, wzrok, słuch, intonacja głosu, jest podstawą relacji $\mathrm{z}$ innym gatunkiem kształtującą się $\mathrm{w}$ orbicie zmysłowocielesno-emotywnej i będącą źródłem komunikacji per se.

Inaczej mają się relacje człowiek - zwierzę z perspektywy masowej gospodarki, gdzie upodmiotowione relacje są wykluczone i zdają się nie znajdować uzasadnienia. Problem dotyczy zwłaszcza warunków bytowania 
zwierząt i traktowania ich przez ludzi w przemyśle mięsnym oraz w badaniach naukowych. Zdrowie fizyczne diagnozowane na podstawie objawów i symptomów fizjologicznych, rozumienie prawidłowych i nieprawidłowych zachowań zwierząt są podstawowymi wskaźnikami dla oceny ich dobrostanu lub jego deterioracji. Czy dostępne współcześnie narzędzia badawcze (znane przede wszystkim medycynie weterynaryjnej) są jednak wystarczające, aby wiedzieć, co czuje zwierzę? Jak zwierzęta odczuwają cierpienie, jak sobie z nim radzą - jak głęboka jest ich bezradność w obliczu cierpień nieznanych im w warunkach naturalnych, a przysporzonych przez stworzone przez człowieka warunki sztuczne, np. wymuszony bezruch kurcząt hodowanych na fermach? Czy wczucie i empatia dają nam podobny obraz stanu zwierzęcia, jaki uzyskujemy, współodczuwając z ludzkim bliźnim, skoro ludzka kondycja różni się od zwierzęcej i bardzo niewiele wiemy o tym, jak to jest być psem czy krową? Ewolucja wiedzy biologicznej i zoopsychologicznej o dobrostanie zwierząt i odstępstwach od nich, a przede wszystkim jej świadome i mądre stosowanie w praktyce mogą jednak przyczynić się do polepszenia warunków bytowych zwierząt w ludzkim świecie (lub w ekosystemie dzielonym przez wszystkie żywe gatunki), przekładając się na etycznie lepsze relacje z nimi, uwzględniające ich autonomię i specyfikę właściwych im gatunkowo potrzeb i sposobów życia:

Tworzenie obrazu element po elemencie (co zwierzę lubi? co stanowi o jego zdrowiu? jakie są oznaki doznawanego przezeń strachu lub frustracji) jest przedsięwzięciem trudnym, wymagającym dokonania podstawowych badań nad każdym ze zwierząt, z którym możemy wejść w kontakt. Jest to jednak rodzaj analogii, która w ostatecznym rozrachunku dostarczy nam realnie jedynie nadziei na możliwość wyzwolenia innych gatunków z obciążeń i możliwość zapoczątkowania tego, że świat będzie postrzegany nie tylko naszymi, lecz także ich oczyma (Dawkins 2006, s. 48).

Bliższa znajomość zwierzęcej perspektywy postrzegania świata, a przede wszystkim ich specyficznego, odmiennego od ludzkiego sposobu odczuwania i postrzegania własnej kondycji m.in. za sprawą zmysłu wewnętrznego (propriocepcji postrzegającej stany wewnętrzne, np. ból, relacje ciała z otoczeniem - np. perforacje, połknięte przedmioty, uszkodzenia ciała etc.) jest tylko $\mathrm{w}$ pewnym stopniu możliwa za sprawą nawiązania przez człowieka bliskich relacji ze zwierzętami i nakładania na zwierzęta schematu analogicznej czy choćby równoprawnej osobowości. Poprzez osobowość należy tu rozumieć szereg „właściwości zdefiniowanych w sposób nieścisły, lecz podpadających pod kategorie jakiegoś konkretnego podzbioru: autonomia, racjonalność, samoświadomość, kompetencja lingwistyczna, towarzyskość, zdolność umyślnego działania, oraz zdolność moralna" (DeGrazia 2006, s. 52).

Ludzkie, nieadekwatne do kondycji zwierzęcej spektrum kryteriów pozwalających jakoby włączać inne istoty w horyzont ludzkiej moralności (vide: 
etycznego traktowania poszczególnych istot zwierzęcych $\mathrm{w}$ sposób zindywidualizowany, w kategoriach podmiotowych) nie może więc stanowić wspólnej miary.. Współczesny filozof umysłu Thomas Nagel stawia pytanie, jak to jest być sobą, będąc np. nietoperzem lub jakąkolwiek inną, nieludzką istotą. Idzie bowiem o „subiektywny charakter doznań” (Nagel 1997, s. 4), który pozostaje dostępny komukolwiek innemu poza podmiotem.

Doznania te również mają $\mathrm{w}$ każdym przypadku pewien szczególny, subiektywny charakter, którego pojąć nie jesteśmy zdolni (...) A odmawianie realności czy sensu logicznego temu, czego wcale nie możemy opisać ani zrozumieć, jest najbrutalniejszą formą dystansu poznawczego (...) Dziś zupełnie brak nam narzędzi, by myśleć o subiektywnym charakterze doznań - nie opierając się na wyobraźni - nie przyjmując punktu widzenia doznającego podmiotu. Należy uznać to za wyzwanie i szukać nowych pojęć i metod (Nagel 1997, s. 4-5, 9)

Jedno $\mathrm{z}$ takich narzędzi - tj. postrzeganie kinestetyczne siebie $\mathrm{i}$ przedmiotów zewnętrznych za sprawą doświadczanych przez obserwatora ruchów własnego ciała (np. gałek ocznych) w powiązaniu z propriocepcją stworzyła klasyczna fenomenologia: „rezultatem tego rodzaju analizy fenomenologicznej jest to, że każda normalna percepcja obejmuje przedrefleksyjne, cielesne samoodczuwanie czy samopobudzanie: milczące doświadczanie siebie samego w spoczynku i w ruchu, milczące doświadczenie siebie samego jako ucieleśnionego sprawcy" (Hanna \& Thompson 2012, s. 33).

Jednakże próby odkrywania związków łączących człowieka z pozostałymi mieszkańcami świata ożywionego mogą też nawiązywać do oryginalnej myśli greckiej, wyrażającej więź między wszelkimi istotami żywymi, a przynajmniej jakąś - chciałoby się powiedzieć: ewolucyjną kontynuację. Tor owej myśli odmienił Arystoteles „budując hierarchiczny, teleologiczny światopogląd skoncentrowany $\mathrm{w}$ istocie bardziej na różnicach aniżeli na podobieństwach" (Cavalieri 2006, s. 57), także międzygatunkowych. Z kolei Kartezjusz wypaczył pierwotny sens tamtej myśli (zainteresowanej wszak w pierwszym rzędzie filozofią przyrody, zanim nie dokonała zwrotu ku filozofii człowieka i społeczeństwa!), sprowadziwszy zwierzęta do kategorii istot nie tylko niezdolnych do świadomego odczuwania cierpienia, ale zgoła pozbawionych duszy, machinalnych czy jedynie „rozciągłych” w rozumieniu res extensa. Radykalny dualizm res cogitans i res extensa prowadzi Kartezjusza, jak wyjaśnia w swojej analizie Kartezjańskiej koncepcji zwierzęcia P. Pasieka, do przekonania, iż zwierzęta obdarzone są zdolnością doznawania i poznawania (a raczej: czegoś w rodzaju proto-poznania lub surowych danych stanowiących punkt wyjścia dla poznania empirycznego) za sprawą zmysłów, jednakże bez udziału świadomości i bez możliwości przekładu i organizacji danych zmysłowych w sposób właściwy tzw. funkcjom kognitywnym umysłu (takim, jak ekspresja w języku artykułowanym bądź w inny, symboliczny i dający się 
dalej rozważać pojęciowo sposób, jak refleksja, analiza, generalizacja, uzasadnienie, rozumienie, interpretacja itd.):

Widzą, słyszą, boją się i radują, lecz wszystkie te odczucia i wrażenia przebiegają bez żadnego myślenia. Wszystkie te uczucia i doznania, stanowiąc fizjologiczne reakcje organizmu, winny być wyjaśnianie wyłącznie w tych kategoriach, bez konieczności uciekania się do terminów 'wolicjonalno-mentalnych' (Pasieka 2012, s. 62).

Choć autor artykułu (który w powyższym przytoczeniu sprowadza percepcję, intuicję, emocjonalność, afektywność i czynności wyobraźni niejako do jednego wspólnego mianownika) dowodzi, że bezzasadnie jest przypisywać Kartezjuszowi odpowiedzialność za rozpowszechnienie praktyk wiwisekcyjnych, to niewątpliwie ten przysłużył się do rozwoju metod eksperymentalnych, scjentyzmu i pozytywizmu, które praktykowały i praktykują na organizmie ożywionym i zgoła żywym (in vivo), z wiwisekcjq włącznie; ich kulminacja miała miejsce w XVIII I XIX stuleciu.

Punktem zwrotnym w traktowaniu zwierząt - w tymże samym, XIX stuleciu - stała się myśl Arthura Schopenhauera, nadająca współczuciu (po okresie dominacji, a zasadniczo: monopolu racjonalnego normatywizmu) kluczową rolę w etyce międzyludzkiej i międzygatunkowej, przychodząc $w$ ten sposób w sukurs odbudowie powiązania między człowiekiem a zwierzętami. Cytowany wyżej Henry David Thoreau okazuje się wobec tego filozofem i etykiem bardziej radykalnym, jeśli chodzi o renesans wspomnianej relacji człowieka do zwierząt ${ }^{1}$. Traktowanie zwierząt $w$ kategoriach zasobów naturalnych i ich zmasowana eksploatacja są podstawowymi przyczynami zakłócenia równowagi ekologicznej na świecie i jednocześnie trwałego, z oporem jedynie poddającego się zmianie usytuowania gatunku ludzkiego $\mathrm{w}$ pozycji zależnej względem zwierząt użytkowych (w szczególności hodowlanych), przy jednoczesnej kontroli sposobów i warunków bytowania zwierząt, skali ich reprodukcji, relacji w stadzie, jakości i częstotliwości odżywiania, programu genetycznego , i na koniec: umierania i uśmiercania. I pomimo tego, że względy eksploatacyjne i konsumpcyjne mogą hamować interwencje ludzkie w sposób i jakość życia zwierząt (np. wraz z rozwojem hodowli ekologicznych, rolnictwa organicznego czy regulacji poziomu antybiotyków, hormonów wzrostu i tzw. chemii w mięsie, mleku, jajach etc.), wzrost ludzkiej wrażliwości na kondycję, los i prawa innych istot żywych i coraz większa świadomość bio-współzależności i potrzeby zachowania

1 Radykalizm Thoreau na rzecz ogranczenia masowej eksploatacji i dewastacji świata ożywionego - także roślinnego - inspiruje współcześnie ruchy ekofilozoficzne. Thoreau twierdził, że „jedyny napój mądrego człowieka stanowi woda. Wino nie jest już tak szlachetnym płynem, a pomyśleć, że nadzieje poranka może zniweczyć filiżanką ciepłej kawy, wieczoru zaś - filiżanką herbaty! Och, jakże nisko upadam, gdy dam im się skusić" (Thoreau 1991, s. 265). 
bioróżnorodności przyczyniają się do poprawy kondycji zwierząt, to oswobodzenie ich spod jarzma wyzysku i eksploatacji nadal pozostaje w sferze utopii. Rewizja stosunku człowieka do tych istot jest może nie tyle kamieniem probierczym ludzkiej moralności (aczkolwiek każda epoka ma swój własny „kamień probierczy”, jeśli idzie o moralność: jednymi z ostatnich takich „kamieni” były zmiany w traktowaniu niewolników, kobiet, dzieci, mniejszości etnicznych, narodowych, wyznaniowych czy seksualnych), ile szansą na jej uwierzytelnienie lub poddanie $\mathrm{w}$ wątpliwość. Systemy moralne zakładają bowiem rozmaite aksjologie, wyobrażenia dotyczące doskonalenia moralnego, normy i reguły; nie znaczy to jednak, że same przez się są doskonałe, zupełne i nie wymagają korekt i rozszerzeń w miarę rozwoju świadomości moralnej i wzrostu liczby wyzwań, problemów bądź konfliktów domagających się rozstrzygnięcia - jeśli rodzą krzywdę, szkodę, niesprawiedliwość. Rozwój horyzontu moralności $\mathrm{w}$ taki sposób, by obejmowała ona $\mathrm{z}$ czasem również osobniki reprezentujące gatunki pozaludzkie, wymaga ponadto restytuowania ich kondycji w kontekście tzw. antropogenu, podtrzymywanego m.in. za sprawą dominujących religii. Nie dotyczy to wszystkich kultur, albowiem te podlegają rozwojowi, proponując ich uczestnikom znacznie więcej aniżeli założenia tradycyjnych wierzeń czy mitów , powstałych przed tysiącami lat. Czy wspólnoty wyznaniowe i religijne powinny zajmować stanowisko wobec wyzwania jakim jest potrzeba zmiany sposobu traktowania zwierząt w świetle wzrostu naukowego poznania warunków ich życia i potrzeb? Być może powinność wyrasta tutaj ze zdolności i gotowości do postawienia sobie takich pytań. „Czy pojedynczy wyznawcy mogą wzbudzić reakcję u przedstawicieli wiodących tradycji religijnych na etyczne aspekty współczesnych praktyk, takich, jak intensywny chów przemysłowy lub dziesiątkowanie dzikiej przyrody?" (Waldau 2006, s. 79). Zapewne indywidualni wyznawcy mogą być źródłem impulsów skłaniających do przyjrzenia się kondycji zwierząt i praktykom ludzkim, od których owa kondycja wydatnie zależy. Indywidualni wyznawcy mogą zmieniać własne nawyki i przyzwyczajenia żywieniowe, dietetyczne, modowe; żaden system norm religijnych nie zawiera nakazu spożywania mięsa ani masowej hodowli zwierząt, a tym bardziej nakazu bezrefleksyjnego zadawania cierpień i męczarni. Z uwagi na siłę i zasięg oddziaływania religii w świecie, autor artykułu upatruje w nich silną rolę opiniotwórczą i wartościotwórczą, jeśli chodzi o poprawę ludzkich relacji nie tylko z otaczającym światem ożywionym, lecz także tym światem ożywionym, który jest masowo wytwarzany i kształtowany przez człowieka podług jego wyobrażeń, technologii i biznesplanów.

Omówiona w tym wstępnym rozdziale sytuacja od wielu lat daje do myślenia etykom i wiedza o niej tworzy już samodzielne dyscypliny, takie, jak etyka praw zwierząt, ekofilozofia, bioetyka, etyka środowiskowa itd. Co innego w przypadku nieporównanie nowszej dyscypliny, jaką stanowi paliatywna 
opieka nad zwierzętami i stosowna etyka, przyświecająca weterynarii paliatywnej. Jej właśnie chciałbym poświęcić główną część tej pracy.

\section{Weterynaryjna opieka i etyka paliatywna}

\subsection{Reżim weterynaryjny}

Relacja opiekuńczo-lecznicza jest jednym z priorytetowych aspektów złożonej relacji człowieka $\mathrm{z}$ innymi gatunkami $\mathrm{w}$ ogóle. Wielowiekowy proces udomawiania zwierząt trwający po dziś dzień dogłębnie i trwale zmienia sposób zachowania, „wygląd, funkcjonowanie i występowanie innych gatunków, a w konsekwencji naszą relację z nimi" (Swabe 2005, s. 18). Ewolucyjne zmiany w trybie życia gatunku ludzkiego, a także zróżnicowanie kultury, w jakich żyją ludzie, wywarły przemożny wpływ na kontakty jego przedstawicieli $\mathrm{z}$ innymi istotami spoza gatunku homo sapiens. Jednym $\mathrm{z}$ punktów zwrotnych owych zmian stało się gromadzenie i przetrzymywanie zwierząt $\mathrm{w}$ skupiskach ( $\mathrm{w}$ tym również zwierząt nie żyjących $\mathrm{w}$ naturalnych warunkach w sposób stadny), domostwach lub w ich sąsiedztwie. Praktyka ta, oprócz licznych korzyści (zarówno materialnych jak i niematerialnych), stwarza między innymi warunki sprzyjające rozwojowi pasożytów, przenoszeniu się infekcji z osobnika na osobnika, wzajemnej agresji, frustracji z powodu zamknięcia, bezruchu, hałasu i stresu. Środowisko hodowlane jest więc środowiskiem silnie chorobotwórczym, sztucznie wytworzonym przez człowieka. „Powszechne choroby zakaźne, takie jak odra, grypa i ospa, które od wieków dotykają ludzkość, dokładnie przypominają choroby, które atakują zwierzęta domowe" (Swabe 2005, s. 35). Z kolei mycobacterium tuberculosis bovis spokrewniona $\mathrm{z}$ ludzkim prątkiem gruźlicy mogła być prawdopodobną praprzyczyną rozprzestrzenienia się tej choroby wśród ludzi. Darwin określał owo podobieństwo jako następstwo „takiej samej struktury histologicznej i składu chemicznego" (Darwin 2009, s. 187) tkanek i wypełniających je substancji u zwierząt i ludzi. Wraz z pojawieniem się chorób zakaźnych oraz epidemii powstała potrzeba ich zwalczania i profilaktyki. Antybiotyki i szczepionki stały się podstawowym środkiem także $\mathrm{w}$ medycynie weterynaryjnej, która pełni funkcję przede wszystkim zapobiegawczą, a w drugim rzędzie - leczniczą, co można zaobserwować w przypadku opieki weterynaryjnej, którą objęte są zwierzęta hodowlane. Biorąc pod uwagę liczne choroby pochodzenia bakteryjnego i wirusowego, których można się nabawić poprzez spożycie produktów pochodzenia zwierzęcego, spośród licznych, np. salmonella, włośnica, listerioza, kampylobakterioza, wąglik, botulizm, tężec, ospa krowia, bruceloza, pryszczyca, wścieklizna, BSE działanie prewencyjne weterynarii jest jak najbardziej uzasadnione. Jego dwuznaczność polega jednak na tym, że stada zwierząt poddaje się opiece medycznej ze względu na służebne (instrumentalne) znaczenie zwierząt dla człowieka lub potencjalne zagrożenie, jakim dla człowieka są choroby odzwierzęce. Należy tu wspomnieć, iż u źródła 
tych chorób - a zwłaszcza mutacji bakterii i błyskawicznego rozprzestrzeniania się infekcji - leży ingerencja człowieka w ekosystem, przedmiotowe traktowanie zwierząt i ich bezwzględna eksploatacja w rażących warunkach bytowych. Paradoksalnie jednak produkty farmaceutyczne medycyny weterynaryjnej takie jak hormony wzrostu, antybiotyki; a ściślej, pozostający $\mathrm{w}$ organizmie potencjalnego produktu mięsnego po ich zastosowaniu osad nie jest obojętny dla zdrowia konsumentów. Swabe sugeruje, iż „ustawiczne aplikowanie antybiotyków może ostatecznie prowadzić do ewolucji patogenów odpornych na takie substancje" (Swabe 2005, s. 103).

Do praktyki weterynaryjnej należy także kontrolowanie rozrodu zwierząt co oznacza sterylizację jak i również opiekę położniczą i poporodową. Zwierzęta poddawane są także rutynowej kontroli, która obejmuje zabiegi, zarówno te koniecznie $\mathrm{z}$ punktu widzenia weterynarii jak i te, których przyczyną są estetyczne kaprysy właścicieli, rehabilitację oraz unicestwianie chorych i rannych zwierząt. Rola weterynarzy jest więc doniosła zarówno w rolnictwie intensywnym, jak i w gospodarstwie domowym. Owa grupa społeczna nie tylko obdarowana jest zaufaniem opiekunów zwierząt, jest ona również odpowiedzialna za utrzymanie zasobów zwierzęcych, od których uzależnione jest społeczeństwo. Emocjonalny związek opiekunów zwierząt z podopiecznymi stanowi rację bytu dla prężnie działającego i rozwijającego się rynku usług weterynaryjnych, który z kolei prowadzi uzależniającą dla klienta politykę medyczną. Gabinety weterynaryjne wypełnione są po brzegi coraz doskonalszymi specyfikami oraz kosztownym sprzętem medycznym, spełniającym standardy współczesnych technologii medycznych. Galopujący rozwój technologiczny wymaga w równym stopniu zaawansowanej edukacji i syntetycznego wglądu $\mathrm{w}$ dostępne praktyki weterynaryjne po to, by wykorzystać jej osiągnięcia w stopniu jak największym, a jednocześnie - by nie wyeliminować z procesu leczenia roli samego pacjenta i opiekuna. W przeciwnym razie stają się oni biernymi uczestnikami reżimu prewencyjnoleczniczego (stąd tytuł niniejszego rozdziału) prowadzonego przez instytucje medyczne (włącznie $\mathrm{z}$ weterynaryjnymi), który oczekuje absolutnego posłuszeństwa wobec obowiązujących procedur i protokołów medycznych, wbijając tym samym klin między racje naukowe, egzystencjalne i etyczne.

Jeśli chodzi o zwierzęta domowe jako grupę podopiecznych o statusie odmiennym niż zwierzęta hodowlane, praktyka weterynaryjna i podejście lekarza, choć w dużym stopniu sprowadzone do kontroli i prewencji, umożliwiają zindywidualizowane traktowanie pacjenta na poziomie diagnostyki, terapii, rehabilitacji, leczenia ambulatoryjnego itd. Emocjonalne przywiązanie opiekunów do podopiecznych sprawia, iż są oni skłonni inwestować znaczące środki finansowe $\mathrm{w}$ poprawę stanu zdrowia swoich pupili, nawet jeśli wiąże się to $\mathrm{z}$ wyrzeczeniami dotyczącymi ich własnego 
dobrostanu. $^{2}$ Taka postawa opiekuna doprowadza niekiedy do sytuacji, w których - mimo silnie obniżonej jakości życia zwierzęcia i tzw. wskazań medycznych - jego opiekun odrzuca myśl o dokonaniu eutanazji jako „wykonalnej alternatywy”, nawet jeśli wydłużanie życia i medykalizacja środkami uśmierzającymi ból i cierpienie nie licują z jego/jej interesem finansowym, a zwierzę nie będzie już w stanie czerpać żadnej przyjemności $\mathrm{z}$ życia i zdrowej kondycji, a przynajmniej nie cierpieć. 0 tym, czy eutanazja jest właściwym określeniem $\mathrm{w}$ przypadku uśmiercania zwierząt $\mathrm{w}$ stanach określanych jako nieuleczalne bądź terminalne, będzie mowa w dalszej części tej pracy.

Obecnie należy zwrócić uwagę na fakt, że praktyka weterynaryjna w stosunku do zwierząt domowych przedstawia ofertę zbliżoną do medycyny ludzkiej, włącznie z usługami stomatologicznymi i chemioterapią nowotworów. Finansowe uwarunkowania procesów leczniczych mają niewątpliwie znaczenie dla postaw lekarzy weterynarii, których praktyki (a zwłaszcza ich skuteczność) wymagają wydatnego udziału technologii medycznych, o których wiadomo, że są kosztowne. Oznacza to, że etyka weterynaryjna ścierać się musi z presją, której źródłem jest rozdźwięk pomiędzy potencjałem leczniczym usług weterynaryjnych a ograniczoną zasobnością ekonomiczną opiekunów. To zaś może sprzyjać rozwiązaniom niekoniecznie pożądanym, a przede wszystkim nadużyciom.

\subsection{Natura ucywilizowana}

Spychając zwierzęta figurujące $\mathrm{w}$ diecie większości społeczeństwa poza granice ludzkich osiedli (zwłaszcza miast), rodzaj ludzki uciszył swoje sumienie i przytępił wrażliwość, przenosząc jednocześnie swoje uczucia - a także głód bezwarunkowych, pozytywnych uczuć, przyjaźni i przywiązania - na zwierzęta domowe, wśród których niewątpliwie królują koty i psy. Ten rozbrat między zwierzętami produkcyjnymi a domowymi zarysowuje się wyraźnie w XX wieku i oprócz tego, że jest szczególnie stymulujący dla rozwoju weterynarii, ma on też znaczenie dla kształtu relacji człowieka z innymi zwierzętami, a także dla ich perwersji i patologii (nie obawiajmy się dosadnych określeń). Tytuł książki autorstwa psycholog Melanie Joy, który w przekładzie polskim brzmi: „Dlaczego kochamy psy, jemy świnie i ubieramy się w krowy," ilustruje nasz ambiwalentny stosunek do innych gatunków zwierzęcych. Brak bezpośredniego kontaktu z przyrodą i jej przedstawicielami skutkuje instrumentalnym traktowaniem zwierząt i promowaniem dwulicowej postawy mięsożernego opiekuna przedstawicieli wybranych gatunków, podczas gdy wcale nie różnią się one od tych, którym nikt nie nadaje imion (lecz co najwyżej numery ewidencyjne) i których nikt nie czyni swoimi towarzyszami, pupilami ani członkami rodziny.

2 Film „Przeprowadzka” w humorystyczny sposób przedstawia tę kwestię na tle dostępnych praktyk weterynaryjnych oraz kosztów z nimi związanych na terenie USA. 
Z perspektywy samych zainteresowanych - czyli zwierząt domowych uwarunkowania, w jakich one powszechnie funkcjonują, nie są $w$ pełni rekompensowane przez korzyści wynikające ze wspólnego zamieszkiwania. Z drugiej strony, dzielenie domostwa z człowiekiem skutecznie chroni je przed o wiele mniej lukratywnymi alternatywami egzystencjalnymi, takimi, jak poświęcenie zdrowia, znośnego samopoczucia i życia w eksperymentach naukowych, szczególnie gdy wykonujący lub legitymizujący je ludzie kierują się wyłącznie karierą naukową, zyskami ze sprzedaży produktów testowanych na zwierzętach i kontrowersyjną zasadą przewagi wartości ludzkiego życia nad wartością życia zwierzęcego, która to przewaga ma jakoby usprawiedliwiać masowe torturowanie zwierząt laboratoryjnych.

Do deficytów środowiskowych, niszczących dla psychiki podopiecznych człowieka, zwłaszcza tak rozwiniętych poznawczo i wrażliwych jak konie i psy, należy też wliczyć miedzy innymi: wielogodzinne okresy przetrzymywania w zamkniętych pomieszczeniach, samotne wyczekiwanie na powrót opiekuna, wymuszenie synchronizacji rytmu fizjologicznego z (często pozbawionym regularności) rytmem życia właścicieli i opiekunów; pospieszne spacery, przekarmianie, przemoc, traktowanie zwierząt $w$ charakterze zabawek, maskotek i prezentów (dopóki są młode i budzą infantylne odczucia). Tym niemniej, opisane deficyty społeczne i opiekuńcze w stosunku człowieka do zwierząt udomowionych to raczej wyróżniki pewnych tendencji, które nie świadczą o powszechnym stanie rzeczy; wielu opiekunów stara się eliminować te problemy. Tworzenie znaczącej dla życia i kondycji żywych istot więzi i praktycznych relacji z nimi stanowi antidotum dla warunków nieprawidłowych, przekonuje Temple Grandin, współautorka pracy pt. Zwierzęta czyniq nas ludźmi: wszak „naturalne życie psa polega na byciu z ludźmi”. Rola opiekuna polega w pokaźnej mierze na zastąpieniu rodzica i niewątpliwym opiekuńczym - paternalizmie. Stąd życie psów, które w sensie genetycznym pozostają wilkami, ale w sensie sposobu życia wiodą żywot w stadle rodzinnym, którym ktoś - człowiek - opiekuje się niekoniecznie z pozycji przywódcy stada, samca bądź samicy alfa, wpisuje się w życie ludzi i na odwrót:

Dobrzy rodzice ustalają zasady i uczą dzieci właściwego zachowania, i właśnie tego potrzebują psy. Powinny się one nauczyć od swoich właścicieli dobrych manier. Jeśli psy nie mają dobrych 'rodziców', zaczynają szaleć i podporządkowują sobie dom, podobnie jak robią to często zepsute dzieci. Nieważne, czy myślimy, że jesteśmy przywódcą alfa, matką czy ojcem naszego psa pod warunkiem, że dobrze go wychowujemy (Grandin \& Johnson 2011, s. 44).

Śledząc historię udomowienia zwierząt, Swabe z kolei podaje, że procesy industrializacji i urbanizacji wpłynęły na zmianę wrażliwości człowieka względem zwierząt. Czy to $\mathrm{z}$ powodu urbanizacji, osłabienia kontaktów z innymi ludźmi, czy też z uwagi na niż demograficzny, potrzebę bytowania $w$ towarzystwie zwierzęcia $w$ warunkach domowych bezsprzecznie 
tłumaczy fakt, że spełnia ono rozmaite funkcje wzmacniające relacje i życie społeczne. Dowodzi się również, że zwierzęta odgrywają pozytywną rolę w rozwoju dzieci, a ponadto, że wywierają one dobroczynny wpływ na przykład na osoby obciążone nadciśnieniem, chorobami układu krążenia i stresem. Ponadto, „zamiast stanowić zamiennik ludzkich kontaktów, zwierzęta domowe, faktycznie przedstawiają rodzaj relacji, której nie zapewniają, bądź też rzadko, kontakty międzyludzkie" (Swabe 2005, s. 119).

Ograniczony kontakt z nimi sprawił, że „populacja miejska została daleko odsunięta od surowych realiów relacji ludzko-zwierzęcej i była mniej skłonna by postrzegać zwierzęta w całkowicie utylitarystyczny sposób" (Swabe 2005, s. 121). Zwierzętami najczęściej spotykanymi w domostwach są koty i psy. Ich naturalne zdolności doceniane przez ludzi, takie, jak żywotność, czujność, umiejętności adaptacyjne i społeczne sprawiają, że z łatwością poddawane są antropomorfizacji. Proces ten sprzyja powstawaniu silnych, trwałych i nierzadko głębokich więzi pomiędzy opiekunami i podopiecznymi. Określenie opiekun, w przeciwieństwie do określenia właściciel, oprócz spojrzenia na inną istotę na poziome praw wyrażających się poprzez opiekę i nadzór, wskazuje też - co stanowi wyznacznik różnicy między tymi określeniami - na podmiotowy czy też umożliwiający podmiotowe traktowanie wymiar relacji, zakładający poszanowanie potrzeb i działań, których podmiotem sprawczym jest zwierzę. Podmiotowe traktowanie obejmuje np. zapewnienie spokoju, legowiska, ruchu, odpowiedniej temperatury, odpowiedniego pożywienia $\mathrm{w}$ odpowiedniej ilości, zabawy lub towarzystwa innych przedstawicieli własnego gatunku zwierzęciu, które tego potrzebuje $\mathrm{w}$ zgodzie z własnym charakterem gatunkowym. Bycie opiekunem (bardziej aniżeli bycie właścicielem lub zgoła 'panem' - wszak również niewolnicy mieli swoich panów) sprzyja również rozwojowi relacji partnerskiej, która może być twórcza dla każdej z zaangażowanych stron. Dla odmiany, określenie właściciel implikuje przedmiotowe traktowanie własności - w przypadku zwierzęcia żywej własności - które niesie ze sobą redukcjonistyczne konsekwencje, tj. częściowe lub nawet całkowite eliminowanie lub ignorowanie aspektów podmiotowych kondycji zwierzęcia. Opiekun innej istoty żywej powinien - jak zauważa przywołana autorka - krzewić świadomość, że intelekt nie jest warunkiem sin qua non przypisania i poszanowania praw podmiotowych bądź osobowych - jest nim raczej wzajemnie kształtująca się relacja. Niewątpliwie ważny głos $\mathrm{w}$ kwestii relacji międzygatunkowych zabiera w swojej książce Biokomunikacja. Jak zwierzęta porozumiewaja się ze światem Honorata Korpikiewicz. Na podstawie obserwacji i eksperymentów, autorka udostępnia obraz zwierząt „myślących i mających świadomość.” Co więcej, pokłada ona w filozofii zdolność krzewienia tej perspektywy widzenia, bo „ona tutaj ponosi, z udziałem swoich skądinąd znamienitych przedstawicieli (Kartezjusza i Kanta), największą winę (Korpikiewicz 2011, p. 263).

\subsection{Komu i nad kim prawo do opieki?}

Obszarem medycyny, który respektuje wolę, intuicje i doświadczenie międzyludzkie i międzygatunkowe jako decydujące w procesie leczenia jest obszar, który medycyna uważa za neutralny wobec dostępnych metod leczniczych. Zawężając swoje działanie do kontroli procesów biochemicznych i 
fizjologicznych, medycyna naukowa przyznaje priorytet terapeutyczny sferze psychologicznej i duchowej, która w pełni dochodzi do głosu w tzw. stanie terminalnym, w sytuacji krańcowej dla życia, kiedy to pacjent zostaje poddany opiece paliatywnej. Światowa Organizacja Zdrowia definiuje opiekę paliatywną jako

działanie, które poprawia jakość życia chorych i ich rodzin stających wobec problemów związanych $\mathrm{z}$ zagrażającą życiu chorobą, poprzez zapobieganie i znoszenie cierpienia dzięki wczesnej identyfikacji oraz bardzo starannej ocenie i leczeniu bólu i innych problemów: somatycznych, psychosocjalnych i duchowych (WHO 2004).

Szeroki zakres działania opieki paliatywnej - aczkolwiek zdefiniowany dopiero w ostatnich dekadach dla weterynarii - jest z pewnością dobroczynny dla osób zdolnych wczuć się w położenie i cierpienie swoich towarzyszy życia, którzy z kolei, zgodnie z ich społecznym statusem - mają być beneficjentami takiej opieki, doświadczając skutków szczerych intencji swoich opiekunów prawnych. Szereg zależności wpisany w relację weterynarz-opiekun-pacjent wymaga głębszego namysłu, aby wytworzyć sobie obraz, tego na czym polega opieka paliatywna otaczająca zwierzę. Zasadniczo funkcjonujemy w „reżimie medycznym”, który nie wkłada maksymalnego wysiłku w edukację medyczną zorientowaną na wzmacnianie samoleczniczych zdolności organizmów istot żywych. Wymagałoby to bowiem współpracy w obszarze diagnozy i sposobów leczenia, a przede wszystkim autonomii pacjenta $\mathrm{w}$ relacji $\mathrm{z}$ lekarzem lub terapeutą. W konsekwencji podlegamy istniejącym konwencjom i korzystamy z przyznanych przez nie przywilejów, pozostając jednocześnie w roli zależnej. W przypadku istot innych gatunków ich status zmienia się diametralnie $\mathrm{w}$ zależności od okoliczności, w jakich się znajdują. Decyzja sądu w sprawie przewozu dziewięciu chartów posłuży za przykład:

Linie lotnicze, które podjęły się przewozu psów, zaniedbały należytej opieki nad nimi, pozostawiwszy je w skwierczącym upale podczas międzylądowania. Psom nie zapewniono też odpowiedniej ilości wody oraz należytej wentylacji, a właścicielowi zabroniono doglądania ich. $\mathrm{W}$ rezultacie siedem psów nie przetrwało lotu, a dwa pozostałe były poważnie chore, gdy dotarły na miejsce. Powód wystąpił o odszkodowanie w wysokości 900.000 dolarów w charakterze rekompensaty za utracone psy i opiekę weterynaryjną nad pozostałymi. Sąd apelacyjny orzekł z kolei, że powodowi należy się 750 dolarów jako równowartość kwoty, na którą ubezpieczono bagaż powoda. W decyzji sądu widać wyraźnie, że psy zostały potraktowane jako własność - tj. bagaż (Bernstein 2004, s. 155).

W kontekście polskim podobny scenariusz jest możliwy, jeśli spojrzeć na ustawę o ochronie zwierząt: 
Art. 1.1. Zwierzę, jako istota żyjąca, zdolna do odczuwania cierpienia, nie jest rzeczą. Człowiek jest mu winien poszanowanie, ochronę i opiekę.

2. W sprawach nie uregulowanych w ustawie do zwierząt stosuje się odpowiednio przepisy dotyczące rzeczy (Dz.U. nr 111, poz. 724).

Jak słusznie dowodzi Alicja Dłużewicz w swoim artykule o szansach i możliwościach przekształcenia praw zwierząt, „pomimo zapewnionej prawnie ochrony, sam język lub sformułowanie dotyczące postępowania wobec zwierząt w przypadkach, które mogłyby zostać pominięte, pozwala na odstępowanie od podmiotowego pojmowania i traktowania istoty żywej zdolnej do odczuwania" (Dłużewicz 2014). Z perspektywy specjalisty w zakresie teorii praw zwierząt, jakim jest Tom Regan, każdy podmiot życia ma wewnętrzną wartość (intrinsic value), której przysługują podstawowe prawa, w tym prawo do poszanowania godności ${ }^{3}$.

\subsection{Lingua animalis}

Kwestia statusu prawnego i moralnego innych istot żywych poza człowiekiem jest ściśle związana z nomenklaturą, która tworzy „nasze” ludzkie horyzonty: poznawczy, aksjologiczny i normatywny. Pomimo niejednej naukowej definicji zwierząt, w tym definicji wskazującej na ciągłość ewolucyjną, powszechnie odgradzamy się nie tylko od zwierząt w ogóle, lecz w szczególności od innych ssaków, postrzegając je w odrębnych kategoriach gatunkowych ze wszystkimi ontologicznymi (inność, obcość, wrogość), biologiczno-ewolucyjnymi (walka o byt, 'albo one albo my', itp.), aksjologicznymi (wzmożona relewancja człowieka, 'odwiecznie' uzasadniona przez - rozmaicie skądinąd interpretowane w swojej polisemii - prawo biblijne), normatywnymi (kto ma jakie prawa i powinności, dlaczego większe lub mniejsze, jak kształtuje się odpowiedzialność, jak silne jest uprzedmiotowienie lub upodmiotowienie i których gatunków pozaludzkich, etc.) oraz praktycznymi (jak ostatecznie ludzie postępują ze zwierzętami i na czym opierają prosperowanie świata społecznego) tego wszystkiego następstwami. Nawet semantyka stosowana przez orędowników praw zwierząt, obejmująca zwroty takie, jak „istoty nieludzkie”, odznacza się według Kemmerer „nieporęcznością i ma to do siebie, że wzmacnia przekonanie o istnieniu dwóch kategorii istot: ludzkich i wszystkich pozostałych" (Kemmerer 2006, s. 11), wyłączonych ze świata ludzkiego i omnipotentnego - lecz ograniczonego co do odpowiedzialności, troski i solidarności - człowieczeństwa, które w tym właśnie punkcie okazuje się wysoce ambiwalentne etycznie. Redukcjonistyczne pojmowanie zwierząt, ich kondycji i ich wartości wewnętrznej wyabstrahowuje gatunek ludzki do tego stopnia, że zupełnie zatraca on intuicję ciągłości, otumaniony innowacyjnymi

3 Uniwersytety Harvard i Georgetown jako pierwsze wprowadziły kursy z praw zwierząt w 1999 r. 
możliwościami ograniczonymi jakoby do własnego gatunku. Tymczasem gatunek ludzki powinien dążyć do odzyskania języka zdolnego wyrażać jego interrelacyjne położenie wobec otaczającego świata, a ściślej: do języka, który wyraża prawa ekosystemu, zdominowanego przez gatunek ludzki. W tym duchu wypowiadali się wielcy myśliciele starożytni tacy jak Konfucjusz i Sokrates, jak też bliżsi współczesności, pośród innych, Emerson i Bergson, doskonale zdający sobie sprawę $\mathrm{z}$ roli języka $\mathrm{w}$ postrzeganiu rzeczywistości i jego na nią oddziaływania. Właściwe zastosowanie języka, a więc takie, które cechuje osobista więź z inną istotą - „przypomina nam o podobieństwach istotnych moralnie i tym samym, może dopomóc nam w procesie określania naszej prawowitej moralnej więzi z resztą zwierzęcego świata" (Kemmerer 2006, s. 11, podkreśl. moje).

Regenerując organiczną tkankę życia, którą tworzy sieć złożona z wielu relacji i współzależności $\mathrm{z}$ innymi, także zwierzęcymi innymi - nie zaś nienaruszalna, wertykalna hierarchia bytów z ludzkością u szczytu - możemy na powrót dostrzec i docenić znaczenie każdego żywego indywiduum dla życia jako całości. Decentralizacja władzy sprawowanej przez gatunek ludzki przywołuje tożsamość, wobec której,

Zapieramy się tego, że jesteśmy zwierzętami i częścią koła życia, częścią łańcucha pokarmowego. Przeczymy, że jesteśmy częścią wielkiej uczty i staramy się z niej wyłączyć, chociaż sami zjadamy miliardy zwierząt, a o wiele więcej pozbawiamy warunków do życia. Jednocześnie odmawiamy siebie wszystkim zwierzętom, nawet po naszej śmierci. Nawet robakom. Dlatego potrzebujemy nowej opowieści o stworzeniu, które połączy nas z przyrodą i z innymi, która da nam siłę i niekoniecznie uczyni nas bogatymi, lecz przywróci nas rzeczywistości (Heinrich 2014, s. 20).

\subsection{Aspekty relacji opiekuńczej}

W relacji opiekuńczej jest miejsce na postawę, której źródło stanowią miłosierdzie i miłość (caritas) ${ }^{4}$, a $\mathrm{z}$ całą pewnością szacunek dla każdego bliźniego spokrewnionego $\mathrm{z}$ nami mocą życia jako takiego. Określenia miłosierdzie, miłość niosą ze sobą także konotacje metafizyczne, a ponadto religijne. Wątpliwość powstaje wówczas, gdy biblijną miłość bliźniego ograniczamy wyłącznie do ludzkich bliźnich, a nawet i tych dzielimy na bliższych, dalszych i wreszcie obcych (najczęściej indyferentnych) dla nas bliźnich. Biblijny kontekst miłości bliźniego rzeczywiście ogranicza ją do braterstwa z ludźmi i tylko ludźmi, w tym także z obcymi i wrogami (Nowe Przymierze). Gorzej ze zwierzętami, które nie potrafią odwzajemnić wobec człowieka ( $w$ analogicznych tych formach ekspresji, jakimi dysponuje właśnie

${ }^{4}$ Definicję konstruuję, korzystając z (OED 2016). Łac. caritas "kosztowność, szacunek, uczucie" (w Wulgacie często tłumaczone jako gr. agape „miłość" - szczególnie chrześcijańska miłość bliźnich - być może, by uniknąć zmysłowego wydźwięku łac. amor), od carus "drogi, ceniony", wartościowy. 
on) szacunku, miłosierdzia, miłości. Jednakże teologia chrześcijańska (innych w tej pracy nie rozważam) nie ogranicza się do tej kwestii języka, promując uprzywilejowaną i najbliższą Stwórcy pozycję człowieka w 'piramidzie' przyrody ożywionej i nieożywionej, lecz bierze pod uwagę „obraz i podobieństwo" człowieka do Stwórcy. Z tego bowiem czerpie chrześcijański teocentryzm, i z tego też czerpie chrześcijański antropocentryzm, gdy tymczasem inne, kosmocentryczne czy też par excellence, witalistyczne filozofie i religie powstałe na Dalekim Wschodzie promowały zazwyczaj ludzkie nastawienie przyjazne zwierzętom, a więc także zorientowane mniej dominująco i mniej utylitarystycznie w stosunku do zwierząt. Jeśli zestawić fragment współczesnego katechizmu Kościoła Katolickiego, głoszący, że „zwierzęta, tak jak rośliny i przedmioty nieożywione, są z natury przeznaczone dla dobra wspólnego przeszłej, teraźniejszej i przyszłej ludzkości" z buddyjską Sutrą (Metta Sutta), która powiada, że „tak jak matka chroniłaby swoim życiem swojego własnego syna, swojego jedynego syna, tak powinno się pielęgnować bezgraniczną uwagę wobec wszystkich istot, oraz miłującą życzliwość wobec całego świata" (Waldau 2006, s. 69), okazuje się, że w drugim przypadku mowa jest o empatycznej i pełnej macierzyńskiej troski empatii (empatheia ${ }^{5}$ ), w pierwszym zaś - o surowym i pragmatycznym paternalizmie człowieka wobec zwierząt.

Uzasadnienia czerpane $\mathrm{z}$ przekazów religijnych nadal odgrywają znaczącą rolę w postrzeganiu relacji ze zwierzęcym innym, tym nie mniej, nie są one już tak dominujące w kontekście indywidualnego traktowania zwierząt, eksplorowanym w niniejszej pracy. Należy jednocześnie dodać, iż wraz z poszerzającą się aktywnością na rzecz praw innych gatunków, a także w miarę pogłębiania się kryzysu ekologicznego ulegają one modyfikacjom. Wymownym tego dowodem mogą być słowa jednej z Encyklik Jana Pawła II:

U korzeni bezmyślnego niszczenia środowiska naturalnego tkwi błąd antropologiczny, niestety rozpowszechniony w naszych czasach (...) Człowiek mniema, iż samowolnie może rozporządzać ziemią, podporządkowując ją bezwzględnie własnej woli (...) Zamiast pełnić rolę współpracownika Boga w dziele stworzenia, człowiek zajmuje Jego miejsce i w końcu prowokuje bunt natury, raczej przez niego tyranizowanej niż rządzonej. Widać $w$ tym przede wszystkim ubóstwo czy raczej miernotę sposobu patrzenia człowieka" (Jan Paweł II 2003, s. 671-672).

\section{Podstawowe kategorie i definicje wyznaczające paradygmat weterynaryjnej opieki paliatywnej}

\subsection{Choroba terminalna i ból}

5 Gr. $\varepsilon \dot{\mu} \alpha \dot{\theta} \theta \varepsilon i \alpha$ (empatheia): "fizyczne przywiązanie, pasja, stronniczość", niem. Einfühlung (wczuwanie się). 
Terminem „choroba terminalna” określa się w medycynie chorobę, której sposoby leczenia są nieznane (jednakże to kryterium spełniają również tzw. choroby nieuleczalne, już to dające się kontrolować medycznie - np. wirus HIV, już to wymykające się całkowicie spod kontroli medycznej; listy takich chorób zmieniają się zależnie od postępów w naukach biomedycznych) i która nieuchronnie prowadzi do śmierci, bądź do tak zaawansowanego stadium danej choroby, że można ją leczyć już tylko objawowo. W terminalnej fazie choroby pojawiają się „charakterystyczne dla ostatniej fazy umierania i niemożliwe do pełnego opanowania środkami medycznymi symptomy narastania nieusuwalnej niewydolności ważnych dla życia narządów, zaburzeń metabolicznych i zaburzeń świadomości" (Górecki 1999, s. 264). Poniższa tabela (Kowalczyk 2012, s. 77), przedstawiająca punkty widzenia lekarza (kolumna 1-3) i chorego (kolumna 4), prócz tego, że ilustruje pięć z najważniejszych objawów występujących $\mathrm{w}$ terminalnej fazie choroby charakterystycznych nie tylko dla homo sapiens ${ }^{6}$ przedstawia także różnice $\mathrm{w}$ jakości sprawowania opieki paliatywnej $\mathrm{w}$ odmiennych środowiskach leczniczych.

\begin{tabular}{|c|c|c|c|c|}
\hline $\begin{array}{c}\text { Gradacja } \\
\text { objawów }\end{array}$ & Hospicja & $\begin{array}{l}\text { Hospicja } \\
\text { domowe }\end{array}$ & Szpitale & $\begin{array}{l}\text { Punkt } \\
\text { widzenia } \\
\text { chorych }\end{array}$ \\
\hline 1 & Ból & Zmęczenie & Ból & Zmęczenie \\
\hline 2 & Jadłowstręt & Ból & Majaczenie & Senność \\
\hline 3 & $\begin{array}{c}\text { Zespół } \\
\text { objawów } \\
\text { niedrożności } \\
\text { jelit }\end{array}$ & Jadłowstręt & Nudności & Ból \\
\hline 4 & $\begin{array}{c}\text { Duszność } \\
5\end{array}$ & Chudnięcie & $\begin{array}{c}\text { Zespół } \\
\text { objawón } \\
\text { niedrożności } \\
\text { jelit }\end{array}$ & $\begin{array}{c}\text { Kserostomia - } \\
\text { zespół } \\
\text { suchości jamy } \\
\text { ustnej }\end{array}$ \\
\hline & Zmęczenie & Duszność & Duszność & $\begin{array}{c}\text { Zespół } \\
\text { objawowy } \\
\text { niedrożności } \\
\text { jelit }\end{array}$ \\
\hline
\end{tabular}

Tabela. 1. Pięć objawów terminalnej fazy choroby.

Opieka nad udomowionymi podopiecznymi w chorobie terminalnej jak i umierającymi w przyjaznych warunkach domowych z wykorzystaniem opieki hospicyjnej lub paliatywnej

${ }^{6}$ Opieka hospicyjna dla gatunków udomowionych jest modelowana na wzór hospicjów dla ich opiekunów i zawiera w sobie wszystkie aspekty opieki leczniczej takie jak: opieka domowa, leczenie bólu, wsparcie w odżywianiu dla podopiecznego w stanie terminalnym (zob. Day By Day 2016). 
zajmuje się fizycznymi, emocjonalnymi jak i duchowymi potrzebami zarówno podopiecznych jak i opiekunów. Wiąże się ona $\mathrm{z}$ tworzeniem i wykorzystywaniem zindywidualizowanego wobec potrzeb podopiecznego leczenia bólu i jego symptomów na podstawie opracowanego przez weterynarza planu leczenia (Kowalczyk 2012, s. 77).

Określenie „choroba terminalna” różni się jednak znaczeniowo od określenia „stan terminalny”, obejmującego ostatni (nieuchronnie końcowy, nieprzesuwalny $\mathrm{z}$ powodu bezradności nauk medycznych i dostępnych środków leczniczych) etap życia, którego jakość i długość determinowane są przez rozmaite naturalne procesy degeneracyjne, np. starzenie się mózgu, mutacje komórek i tkanek (im dłużej jedna i ta sama komórka się dzieli, tym częściej w jej młodszych kopiach dochodzi do mutacji patogennych, chromosomalnych i genetycznych, a także mutacji na poziomie fenotypowej ekspresji genów, czyli syntezy łańcuchów białkowych - ostatecznie zaś na poziomie struktury i funkcjonowania tkanek i narządów), i wreszcie przez schorzenia i zwyrodnienia doraźne i uleczalne oraz schorzenia i zwyrodnienia chroniczne, odporne na terapię i ostatecznie - nieuleczalne bądź też nieuleczalne i zarazem przyspieszające śmierć organizmu. „Choroba terminalna” jest zatem określeniem wieloznacznym, odnoszonym z reguły do chorób postępujących (i nasilających się $\mathrm{w}$ związku $\mathrm{z}$ tym postępem degeneracji, dysfunkcji i dolegliwości, których łagodzeniem zajmuje się z kolei opieka paliatywna), takich, jak np. nowotwory złośliwe. W weterynarii właśnie nowotwór jest uważany za główną, zabójczą chorobę, często dotykającą psy (pomijając dysplazję stawów u ras hodowanych wsobnie, a także perforacje przewodu pokarmowego i zakażenia np. sepsą). Wśród psów i kotów częstotliwość występowania niektórych z nowotworów jest znacznie większa niż u ludzi. Przykładowo, psy „35 razy częściej niż ludzie doznają nowotworu skóry, 4 razy częściej raka piersi, 8 razy częściej raka kości i dwa razy częściej zapadają na białaczkę" (Pinney 2004, s. 666). Warto byłoby zbadać przyczyny tego stanu rzeczy, tkwiące być może w przemianach, jakim podlega sposób udomowienia i koegzystencji człowieka ze zwierzęciem, upodobniony tryb życia, dieta, ale być może znacznie większa podatność na choroby nowotworowe, spowodowana krzyżowaniem ras i hodowlą psów rasowych.

Dostępne metody lecznicze w wypadku chorób nowotworowych stanowią kombinacją terapii obejmujących „chemioterapię, naświetlanie, immunoterapię, i/lub operację" (Pinney 2004, s. 671). Leczenie bólu (zwłaszcza analgezja pooperacyjna) jest niezbywalną częścią procesu leczniczego; podobnie uśmierzanie bólu i innych dolegliwości pacjentów chorujących na nowotwory. Ból według definicji Międzynarodowego Stowarzyszenia Badania Bólu to „nieprzyjemne doznanie czuciowe i emocjonalne, związane z rzeczywistym lub potencjalnym uszkodzeniem tkanek bądź opisywane w kategoriach takiego uszkodzenia" (IASP 1994). 
Koncentrujemy się tutaj na bólu fizycznym (somatycznym) i przyjmujemy, że można o nim mówić jako o kategorii łączącej człowieka i inne gatunki zwierzęce w myśl tego, co powiada Emmanuel Levinas:

Levinas jako pierwszy docenił myśl Husserla, podług której ludzkie życie splata się ze światem przyrody. Fundamentalna zasada ożywionego i wrażliwego ucieleśnienia (corporeality, body, Leib w odróżnieniu od prostej materialności i fizyczności, Körper) wskazuje, iż realność człowieka jest ściśle powiązana ze sferą animalną (animalia) - należącą do istot ucieleśnionych, których świadomość wiąże się $\mathrm{z}$ ich żywotnością (vital existence), żywotność ją bowiem częściowo generuje (Altez-Albela 2011, s. 37).

Przytoczona uprzednio definicja bólu zakłada zdolność do artykulacji werbalnej i zdolności językowo-opisowe; w związku z tym proponuje się inne definicje bólu, znajdujące zastosowanie wśród przedstawicieli gatunków nieposługujących się językami, jakimi włada homo sapiens. „Ból u zwierząt to awersyjne doznanie czuciowe związane $\mathrm{z}$ rzeczywistym lub potencjalnym uszkodzeniem, które wywołuje ochronne reakcje motoryczne i wegetatywne, prowadzi do wyuczonego nawyku unikania i może modyfikować zachowania gatunkowe, włącznie z zachowaniami społecznymi" (Latham 2010, s. 85). W praktyce weterynaryjnej wyróżnia się ból fizjologiczny i patologiczny (lub kliniczny), który jest rozpoznawalny i częściowo mierzalny za pośrednictwem rozmaitych specyficznych reakcji fizjologicznych i odruchowych. Towarzyszy mu wzrost rytmu serca i ciśnienia krwi, zwężenie światła naczyń, wzrost częstotliwość oddychania, powiększenie źrenic, a także hiperglikemia; objawy te mogą być podstawą oceny bólu; ale mogą się również wiązać z reakcjami wywołanymi przez niecodzienne środowisko lub wcześniej podane leki i inne stresujące czynniki. Do oceny bólu wykorzystuje się liczne i szczegółowe określenia, jak te przedstawione poniżej:

\section{Podstawowe definicje terminów stosowanych przy artykulacji bólu w ogólności i przy artykulacji bólu towarzyszącego nowotworowi złośliwemu w szczególności:}

Ból ostry (acute pain): pojawia się przy urazach somatycznych, zanika wraz z postępami leczniczymi i ma skłonność do samoograniczenia.

Ból przeszywający (breakthrough pain): czasowo zaostrzający się ból przy towarzyszącym bólu chronicznym, który może się pojawić nawet, gdy ból chroniczny jest kontrolowany.

Ból chroniczny lub przewlekły (chronic pain): trwa od kilku tygodni do kilku miesięcy i utrzymuje się dłużej niż oczekiwany czas leczenia, gdy nowotwór ma pochodzenie niezłośliwe. 
Ból o podłożu nowotworowym (cancer pain): może być ostry, chroniczny lub przerywany (napadowy) i wiąże się z samą chorobą lub jej leczeniem.

Analgezja zapobiegawcza resp. profilaktyczna (pre-emptive analgesia): polega na podaniu środka przeciwbólowego przed pobudzeniem, aby zapobiec nadwrażliwości neuronów i w ten sposób poprawić skuteczność działania tegoż środka.

Anestezja miejscowa (local anesthesia): synonim tymczasowego zaniku czucia w określonym miejscu lub organie ciała, bez utraty świadomości.

Ból neuropatyczny (neuropathic pain): ma źródło w uszkodzeniu obwodowego lub centralnego układu nerwowego i jest opisywany jako palący lub rwący; prawdopodobnie jest on związany z deficytami motorycznymi, czuciowymi i autonomicznymi.

Anestezja częściowa (regional anesthesia): zanik czucia w obszarze ciała, spowodowany blokadą przewodnictwa nerwowego.

Ból somatyczny (somatic pain): ma źródło w uszkodzeniu kości, stawów, mięśni lub skóry. Ludzie opisują go jako 'zlokalizowany', stały, a zarazem ostry, pulsujący. Charakteryzuje się bolesnością samoistną lub spowodowaną uciskiem.

Ból trzewny (visceral pain): powstaje wskutek rozciągnięć, napięć, zapaleń organów wewnętrznych i jest opisywany jako głęboki, skurczowy, dokuczliwy, nękający, niezlokalizowany, rozlany, tępy.

Ból pourazowy lub okołooperacyjna nadwrażliwość (wind-up) wiążą się ze wzrostem pobudliwości neuronów rdzenia kręgowego, która nasila ból pooperacyjny.

Tabela 2. Klasyfikacja rodzajów bólu (za: Gaynor 2008, s. 1430).

Istnieją także narzędzia umożliwiające pomiar bólu (o różnej dokładności, jednak ich użytkownicy dążą do uzyskania optymalnych pomiarów), takie, jak skala bólu stworzona na Uniwersytecie Stanu Colorado, stosowana w diagnostyce kocich i psich pacjentów. Skala ta stanowi „kombinację obrazków i zwrotów wykorzystywanych do oceny postawy psychologicznej i behawioralnej, jak i również do oceny reakcji na dotyk i napięcie ciała" (Sager 2012, s. 472). Weterynarz porównuje $\mathrm{z}$ nimi symptomy $\mathrm{w}$ zachowaniu zwierzęcia, zaobserwowane przez siebie bądź przez opiekunów zwierzęcia. Medycyna potrzebuje możliwie najdokładniejszych informacji dotyczących bólu, ponieważ jej celem jest leczenie i uśmierzanie bólu. W relacji osobistej natomiast nasza ludzka postawa jest wypełniona współodczuwaniem, które nie musi spełniać warunku artykulacji i przekładalności na jakikolwiek język symboliczny czy kryteria naukowe; może się ono przejawiać w towarzyszeniu cierpiącemu zwierzęciu i opiece nad nim, obejmującej przede wszystkim uśmierzanie cierpienia (często jest to profesjonalna interwencja weterynaryjna, którą opiekun organizuje dla zwierzęcia, stając się rzecznikiem 
jego żywotnych potrzeb). Należy nadmienić, że słowna, a nawet metaforyczna deskrypcja bólu i jego ocena na podstawie widocznych symptomów bólu są często niemiarodajne i płynne. Język mający wspomagać komunikację, w którym opisuje się obserwowane symptomy, nie sprzyja translacji wewnętrznego i niepodzielanego z żadną inną istotą doświadczenia na terminy i symbole; te ostatnie mogą sprzyjać zniekształcaniu, ukrywaniu i krążeniu dookoła problemu, zanim dobrana zostanie adekwatna forma pomocy medycznej i farmakologicznej. Zasoby językowe i umiejętność posługiwania się nimi w zawodach medycznych - a więc także w weterynarii - są ograniczone (nie tylko gatunkowo specyficzne); jak bardzo ograniczone i specyficzne, o tym przekonujemy się przy każdej próbie nawiązania kontaktu międzygatunkowego i zrozumienia zwierzęcia w jego „odmienności”, jeśli oczywiście unikamy tworzenia monologów na temat istot żywych bez ich udziału, odpowiedzi, i jedynie $\mathrm{w}$ retoryczno-intencjonalnym związku $\mathrm{z}$ nimi (tzn. mamy intencję porozumienia, lecz konstruujemy językowo nieadekwatny obraz kondycji zwierzęcia). Wobec tego naturalne gesty, ekspresje motoryczne i sygnały, które dzielimy z innymi gatunkami, bywają „o wiele bardziej elokwentnymi i przekonującymi symbolami pierwotnych stanów świadomości, takich jak miłość, pożądanie, strach i ból, aniżeli szekspirowska angielszczyzna" (Rollin 2011, s. 156).

\subsection{Opieka paliatywna i umieranie}

Ogólne symptomy stanu zdrowia zwierzęcego podopiecznego - na przykład psa - podczas choroby terminalnej, takie, jak brak koordynacji, znużenie, brak apetytu, wymioty, nietrzymanie moczu lub stolca, panika, apatia i brak zainteresowania otoczeniem, drgawki, etc. (Roper 2013) wyznaczają kształt i typologię możliwej opieki w weterynarii paliatywnej. Kształt ten jest odmienny aniżeli w przypadku opieki paliatywnej nad człowiekiem, który ma świadomość swojego położenia, a ponadto, doświadczenia i uczucia egzystencjalne (poczucie lęku, przemijania, trwogi, rezygnacji itd; intuicyjnie wiemy, że część tych odczuć dzielimy ze zwierzętami kręgowymi, tyle, że przejawiają się one u różnych gatunków na różne sposoby i mamy nikłą wiedzę o tym, w jaki sposób doświadczają ich zwierzęta).

Mając na uwadze etapy psychologiczne towarzyszące perspektywie nadchodzącej śmierci u człowieka, które Kübler-Ross (1998) uszeregowała jako zaprzeczenie i izolację, gniew, targowanie się, depresję i pogodzenie się, można się jedynie domyślać, że również zwierzęta kręgowe, posiadające świadomość bólu, zdolne cierpieć psychofizycznie i doświadczać stanów depresyjnych i traumatycznych, przechodzą przez te stadia na swój własny sposób, być może z tą różnicą, że zamiast procesu poznawczego jaki prowadzi u człowieka do pogodzenia się ze swoim stanem za sprawą rozumienia, uzasadnienia i aktu wolicjonalnej akceptacji, zwierzęta przyzwyczajają się i 
przywykają do swojej kondycji $\mathrm{w}$ chorobie lub też popadają $\mathrm{w}$ rezygnację $\mathrm{i}$ bezradność, nie wiedząc, jak się swojemu dziwnemu, wewnętrznemu wrogowi przeciwstawić, i nie zdając sobie sprawy $\mathrm{z}$ tego, że znajdują się $\mathrm{w}$ stanie terminalnym. Jednak zwierzęta również odczuwają lęk przed śmiercią, a nawet lęk przed zmianą miejsca zamieszkania i utratą kontaktu $\mathrm{z}$ opiekunem. Wszystkie sygnały „zmiany” w życiu zwierzęcia są dla niego niepokojące.

Terapia medyczna w chorobie terminalnej może mieć również działanie osłabiające i powodować niechciane, uciążliwe skutki uboczne; przy chemioterapii są to nudności, wstręt do spożywania płynów, wymioty, biegunka, a także wzmożone pragnienie i oddawanie moczu w przypadku radioterapii (Arden 2003, s. 188-198). Niemniej jednak, w przypadku chorób nieuleczalnych, spektrum działań leczniczo-opiekuńczych jest szerokie i rozciąga się między możliwościami oferowanymi przez medycynę konwencjonalną i niekonwencjonalną. Opieka paliatywna jest proponowana wszystkim pacjentom niezależenie od przyjętego stylu leczenia. Może być udzielana przez osoby z odpowiednim przygotowaniem lub też samodzielnie przez opiekuna poinstruowanego przez prowadzącego leczenie lekarza weterynarza. „Niektóre programy hospicyjne przewidują okazjonalne wizyty domowe weterynarza lub technika weterynarii w celu udzielenia wsparcia opiekunowi i ewaluacji" (Eldredge et al. 2008, s. 542) przebiegu opieki. Często odnotowywanym objawem zbliżania się do kresu życia jest odmawianie jedzenia i dążenie do odosobnienia (Pinney 2004, s. 647), co przy właściwej opiece nie musi potęgować cierpienia, a wręcz może prowadzić do poprawy stanu zdrowia czy ogólnej kondycji organizmu (organizm w stanie choroby samoistnie wstrzymuje się od jedzenia, mobilizując siły na walkę z procesami chorobowymi jako „ciałem obcym”; organizm traktuje w taki sposób zwłaszcza infekcje i urazy).

Jednym z poglądów na temat łagodnego umierania jest odejście we śnie, pod nieobecność świadomości (a także aktywnej relacji z pozostającymi przy życiu). Jednak jest to ludzki punkt widzenia, według którego przypuszczalnie ten sposób rozstania $\mathrm{z}$ bliską istotą pozwala zachować $\mathrm{w}$ pamięci iluzję ciągłości relacji poprzez wspomnienie odchodzącego jako istoty żywej (mamy tendencję do pamiętania o bliskich jako żywych, nie tylko tendencję do „ożywiania” ich poprzez pamięć). Może się jednak zdarzyć, że ulga niesiona bliskiej istocie w cierpieniu będzie zależna od woli i aktywności opiekuna, czyli jego udziału w opiece obejmującej także opuszczenie świata życia. Więź między człowiekiem a zwierzęciem, pogłębiając się w miarę upływu lat, sprzyja właściwemu odczytywaniu i interpretacji stanu zdrowia podopiecznego, choć nie należy polegać jedynie na intuicjach i przeczuciach. Konsultacja weterynaryjna może ukazać obraz kondycji ukochanej istoty w wymiarach bardziej realistycznych i przede wszystkim pozwalających na organizację skutecznych działań przedłużających życie i zapewniających względny dobrostan nawet w przypuszczalnie niedługiej, ostatniej fazie życia, o jakiej 
mówią rokowania medyczne. Wspomniany już wcześniej zasięg i możliwości medycyny weterynaryjnej oraz psychologiczno-duchowy wymiar opieki paliatywnej mogą skutecznie wspomóc relację z podopiecznym u schyłku życia, podczas choroby terminalnej lub w nagłych wypadkach, które przerywają życie nagle i brutalnie. Wobec pogarszającej się kondycji podopiecznego, a zwłaszcza wobec cierpień i zaniku podstawowych funkcji fizjologicznych (o radości życia i dobrostanie nie wspominając), pomimo wszelkich podjętych starań, stajemy przed decyzją o dokonaniu eutanazji, która ciąży na Naszych barkach i w przypadku zwierząt udomowionych jest konsekwencją tego, że człowiek przejął je $\mathrm{w}$ dużej mierze od sił natury i siłom natury do tej pory się przeciwstawiał: w „naturalnych” warunkach bowiem zwierzę nie dotrwałoby do tego momentu.

Opieka paliatywna bezsprzecznie stwarza warunki do spotkania i porozumienia bardziej osobistego i nieformalnego, werbalnego lub pozawerbalnego, na poziomie psychicznym, duchowym (przy całej dojmującej wszechobecności czyjejś cielesności, fizjologii, słabości, bezradności w życiowym funkcjonowaniu), jeśli idzie o człowieka; i niewykluczone, że na podobnym poziomie takie porozumienie możliwe jest między człowiekiem i wyższymi zwierzętami kręgowymi. Refleksje nad kilkunastoletnim stażem jednej $\mathrm{z}$ pielęgniarek działających $\mathrm{w}$ opiece paliatywnej wskazują na doświadczenie opiekuńcze jako drogę ku przemianie własnej osobowości w kierunku realizacji osobistej wizji praktyki. „Świadoma opieka to znakomicie wykształcona zdolność koncentracji na sobie (...) w taki sposób, aby pozostawać w pełnej gotowości niesienia ulgi w cierpieniu" (Johns 2004, s. 18) innej żywej istoty.

Słowa te uświadamiają, że gotowość pomocy w odpowiedzi na (nieme często) wezwanie do pomocy, jakiej potrzebuje drugi, jest dla mojej osoby wyzwaniem mobilizującym wszystkie siły, całą energię; nie zaś okazją do projekcji własnych priorytetów i koncentracji na sobie. Koncentracja oznacza tu koncentrację siebie zorientowaną na innego. „Subtelna praktyka opiekuńcza byłaby więc współbytowaniem mojego ja z pacjentami i rodzinami w sposób świadomy, z intencją łagodzenia cierpienia i promowania rozwoju poprzez przekierowanie doświadczenia choroby ku bardziej harmonijnemu poczuciu dobrostanu" (Johns 2004, s. 19). Opieka paliatywna jawi się z jednej strony jako kolejny etap wspólnych przeżyć, które koordynuje opiekun, a których beneficjentami są obie strony: zarówno ta zaangażowana $\mathrm{w}$ terapię jak i ta, która jest jej przyczyną i obiektem. Przy tak rozwiniętej samoświadomości kontakt z drugą istotą osiąga wymiar pełnego wzajemnego zrozumienia - przy pełnej asymetrii tego, kto potrzebuje pomocy i tego, kto jest w mocy ją świadczyć - które zabezpiecza przed uporczywym wydłużaniem bądź nagłym przerwaniem procesu terapeutycznego (który jednak nie jest tym samym co proces leczniczy) przez opiekuna. Schyłkowy etap relacji $\mathrm{z}$ natury nosi znamiona terapeutyczne, skuteczne pod warunkiem właściwego 
przygotowania i nastawienia świadomości. W opiece paliatywnej, której podstawowym składnikiem jest jakość współobecności, komunikacja zajmuje miejsce naczelne. „Uwaga skupia się na wszystkim, co jest wciąż możliwe w tym czasie wielokrotnych strat, na poszukiwaniu znaczenia przez pacjenta i rodzinę, a także na podtrzymywaniu doświadczenia wspólnej więzi w procesie adaptacji do wyzwań chwili" (Fallon \& Hanks 2006, s. 1). Komunikacja to tutaj przede wszystkim responsywność, odpowiadanie na niewypowiedziany niepokój, na niemą potrzebę, na milczenie i nieprzekazywalność cierpienia (bo cóż tak naprawdę jest w stanie adekwatnie je wyrazić? i któż jest władny mieć w nim udział - wszak nawet współczucie i empatia nie polegają na tym, by cierpienie z kimś dzielić i przez to właśnie - podwajać i pomnażać); oswojenie, a może też pomoc $\mathrm{w}$ pokonaniu tego stanu przez pacjenta stanowi o wartości i skuteczności terapii paliatywnej.

\subsection{Moralność empatii}

Relacja między człowiekiem i „inną” żywą istotą jest kluczowa przy rozpatrywaniu stanowiska moralnego, uzasadniającego szereg decyzji opiekuńczo-leczniczych, a także decyzji w obliczu stanów terminalnych, jakie podejmuje się $\mathrm{w}$ instytucjach świadczących opiekę paliatywną. Niewątpliwie żywimy empatię o podłożu emocjonalnym i otaczamy uczuciowym zaangażowaniem i troską tych, z którymi bezpośrednio koegzystujemy lub z którymi zdecydowaliśmy się koegzystować, nie wyłączając z tej orientacji rozmaitych przypadków relacji socjopatycznych. Ale empatia, szacunek, pomoc i zaangażowanie mają też inne, daleko głębsze i trwalsze korzenie np. $\mathrm{w}$ tzw. świadomych uczuciach moralnych: poczuciu odpowiedzialności, solidarności, poczuwaniu się do pomocy, poczuciu życzliwości i braterstwa, które są niezależne od okazjonalnych stanów emocjonalnych, a także wiedzy lub niewiedzy o tym, z kim mamy do czynienia (przyjmując za fenomenologią i hermeneutyką, że poznanie „inności” nie jest możliwe: możliwe i etycznie zalecane jest jej rozumienie nawet, jeśli „inny” nie jest istotą myślącą, a jedynie czującą, albowiem czująca i doświadczająca istota - nie mniej, aniżeli istota myśląca - zasługuje na „rozpoznanie”, przez co Ricoeur, oprócz identyfikacji, rozumie także „uznanie” (Ricoeur 2004, s. 42-48) (recognize/erkennen w odróżnieniu od czysto chłodnego aktu poznania). Jeśli „ja” spotykam „innego”, odznaczającego się podmiotowością (niech to będzie inny człowiek albo wyższe zwierzę, obdarzone instynktami i świadomymi emocjami, a może jakąś formą świadomości niewerbalnej), to rozpoznanie w rozumieniu Ricoeur, nie jest aktem przyswojenia przedmiotu i aktem poznania jakiejś obiektywnej i jednej „prawdy” o nim, lecz aktem rozumienia właśnie „kogoś” a nie „czegoś, jako rozumienia, w którym zawiera się zarówno rozpoznanie jak i uznanie nienaruszalności podmiotowości będącej źródłem intencjonalnych zachowań. Taki podmiot uznaję za równoprawny „mnie” co do jego statusu nierzeczowego, przy całej różnicy, jaka między nami zachodzi i której - jako 
istota innego gatunku - nie potrafię oszacować ani rozpoznać nawet za pomocą analogii. Rozumienie może być prawdziwe na tysiąc sposobów: może być (choć nie musi) także podzielane przez różne podmioty. Nie jest gotowe, jak pewne formy poznania i wiedzy; zależy od zdolności podmiotu i zmiennej, niegotowej tkanki życia i doświadczenia. Podmiot może rozumieć inny podmiot na podstawie najprzeróżniejszych, obserwowalnych przejawów i sposobów uzewnętrzniania się jego aktywności. Jedyna przeszkoda, która nie pozwala poprowadzić tego rozumowania tak daleko, jak w przypadku "ludzkiego” podmiotu jest taka oto: zwierzę nie jest twórczym inicjatorem i sprawcą działań i zachowań o takim spektrum i takiej jakości, jakie filozofia hermeneutyczna (i fenomenologiczne, badane przez nią doświadczenie) przypisuje człowiekowi. Poza gatunkiem homo sapiens istnieją jednak istoty, które uczą się języka od swoich rodziców i tworzą własną formę życia, której poznawaniem zajmują się np. etologia (nauka o zachowaniu zwierząt) i antropologia filozoficzna, badająca różnice między człowiekiem i zwierzęciem.

Zatem rozpoznanie, rozumienie i uznanie w sensie Ricoeurowskim jest aktem raczej jednostronnym i asymetrycznym: zwierzę może 'odpowiedzieć' człowiekowi rozumieniem i uznaniem w inny sposób niż czyni to człowiek wobec niego. I nie jest to zapewne tylko różnica języków i kodów komunikacyjnych, lecz także różnica ilościowa i jakościowa, różnica na poziomie motywacji, potrzeb, zdolności i środków, jakimi zwierzę dysponuje.Pomimo tych ograniczeń i ontologicznej asymetrii człowiek zwierzę, jednostronny akt traktowania zwierzęcia „podmiotowo” jest bardzo znaczący dla obu stron: moralnie dla człowieka, a bytowo i życiowo dla pojedynczych egzemplarzy jak i gatunków spoza kręgu homo sapiens. Oznacza on przejście od przedmiotowego, zreifikowanego statusu zwierząt ku statusowi podmiotowemu. Jeśli zaś człowiek chciałby wytworzyć sobie względnie „jasne i wyraźne" (mówiąc językiem Kartezjańskim) pojęcie na temat zwierzęcej podmiotowości, musiałby odkryć jakąś metodę oferującą pewność poznawczą. A tej nie jest w stanie dać mu nawet 'poznanie' innej ludzkiej osobowości; w związku z tym nawet psychologia pozostaje bardziej rozumieniem niż poznaniem podmiotowości innego człowieka. Z pewnością nie wystarczyłoby do tego wejście w przysłowiową już skórę nietoperza (jak powiada cytowany wcześniej Nagel) i doświadczenie, jak to jest być nietoperzem dla nietoperza a nie dla człowieka z uwagi na odmienność zmysłowych i umysłowych warunków doświadczenia i poznania.

Takie „rozpoznanie” i „uznanie” przekładałoby się na responsywność, czyli odpowiedź w formie działania, rozumianego tutaj jako aktywna, bezwarunkowa, bezinteresowna, anonimowa pomoc (i tu decentracja „ja”, opisana przez pielęgniarkę, spotyka się $\mathrm{z}$ niepoznawalnym ale rozpoznawalnym i uznawalnym „ty” Ricoeura) świadczona innemu (aczkolwiek osoby wybitnie do takiej pomocy uzdolnione stają się $\mathrm{w}$ oczach opinii publicznej osobistościami moralnymi, takimi, jak Matka Teresa z Kalkuty). Jeśli 
tym innym jest zwierzę (co oczywiście wykracza poza ramy fenomenologii i hermeneutyki $w$ zakresie proponowanym przez Levinasa i Ricoeura), to pomoc może być równie bezwarunkowa, bezinteresowna i anonimowa, jak dowodzi tego działalność takiej osobistości moralnej, jaką jest Dorota Sumińska, nie zważająca na zaburzenia $\mathrm{w}$ zachowaniu zwierząt bezdomnych i adoptowanych, lecz kierująca się „rozpoznaniem” i „uznaniem” ich indywidualnej wartości jako żywych istot które znalazły się w potrzebie, zarówno tych o znanym i imponującym, jak i tych o niewiadomym i skromnym rodowodzie czy życiorysie.

Dokładając starań w rozumieniu podopiecznych, nie stajemy się uosobieniem nieskazitelnej troski i pomocy za sprawą samej tylko dobrej woli; niezbędne są tutaj inne szlachetne, a czasem bardzo proste cechy charakteru, takie, jak cierpliwość i takie, jak zdolność zorganizowania adekwatnej pomocy. Indywidualna kondycja ludzkiej moralności w zestawieniu z instynktami zwierząt może być przyczyną frustracji, a nawet agresji wobec podopiecznych. Dorota Sumińska i jej akcja „Wierzę w zwierzę” daje przykład tego, jak człowiek powinien sobie radzić zarówno z podopiecznym zwierzęciem, jak i sam ze sobą w relacji do zwierzęcia.

Niechybnie człowiek jest zdolny korygować własne zachowania, rozumieć, wyrażać i temperować własne emocje, a tym samym, rozwijać postawy ułatwiające nawiązanie kontaktów wspierających koegzystencję ze zwierzęciem i trwanie przy nim do końca w doświadczeniu, które - jako istota ucieleśniona i ożywiona - z nim, przypuszczalnie w znacznej mierze (acz wciąż nieporównywalnej dla żadnej ze stron, co z kolei wykazał Nagel), dzieli.

Jak przekonuje De Waal, empatia „jest pierwotną, przedjęzykową postacią związku międzyosobniczego, który dopiero w toku dalszej ewolucji znalazł się pod wpływem języka i kultury" (De Waal 2013, s. 47), lecz przecież istnieje niezapośredniczony symbolicznie język empatii, sposoby zachowania, a nawet wytwory kulturowe, który nie unicestwiają empatii i nie przerywają więzi człowieka z innymi istotami żywymi, lecz pozwalają ją pielęgnować. Partykuła dopiero w wypowiedzi De Waala sugeruje, jakoby kultura oddziaływała inwazyjnie czy wręcz destrukcyjnie na ewolucyjną ciągłość rozwoju zwierzęcych afektów społecznych. Prymatolog powołuje się na wyniki badań i wyraża jednocześnie zdziwienie na myśl, iż „w przypadku cech ludzkich takich jak empatia, które są tak wyraźne i rozwijają się wcześnie w życiu osobniczym, mają ważne neuronalne i fizjologiczne korelaty, a także genetyczny substrat” mogłaby nie istnieć „ewolucyjna ciągłość między ludźmi a innymi ssakami" (De Waal 2013, s. 48). W podobnym duchu pisał Darwin - i to nie tylko w dziele $O$ pochodzeniu człowieka:

Wielu przyrodników, przez wzgląd na wysoko rozwinięte władze psychiczne człowieka, podzieliło świat organiczny na trzy odrębne działy: ludzki, zwierzęcy i roślinny. Ale jakim prawem w celu klasyfikacji przyrodnik może posługiwać się samymi 
władzami psychicznymi? Czyż nie racjonalnej będzie wykazać, jak to uczyniłem, że duchowe zalety człowieka nie różnią się od zwierzęcych co do jakości, różniąc się jedynie co do stopnia? A jeśli tak jest, to przecież różnica stopnia, nawet wielka, nie usprawiedliwia bynajmniej takiego podziału i nie daje prawa do utworzenia odrębnego działu dla człowieka" (Darwin 2009, s. 182).

I dosadniej w ostatnich zdaniach rozdziału zatytułowanego Genealogia człowieka i jego pokrewieństwo:

Dzisiejsza nauka stoi już na tym poziomie, że trzeba chyba zamknąć oczy, aby nie widzieć węzłów pokrewieństwa łączących człowieka z innymi zwierzętami, węzłów, których wcale nie potrzebujemy się wstydzić (Darwin 2009, s. 206).

Tzw. teorii fasady, wedle której moralność jest „sztucznym tworem narzuconym przez kulturę, całkiem sprzecznym z ludzką naturą" (De Waal 2013, s. 40), De Waal przeciwstawił ewolucyjnie uwarunkowaną etykę Teoria ta „postuluje ciągłość między moralnością człowieka a skłonnościami społecznymi zwierząt” (De Waal 2013, s. 45). Poszerzając określenie empatii o pokrewne mechanizmy współczucia i osobistego niepokoju, prymatolog rozróżnia pomiędzy tzw. zakażeniem emocjonalnym (automatycznym udzielaniem się emocji) a empatią mającą podstawy świadome i poznawcze, obejmującą ocenę cudzego położenia, jak też własnych emocji. Przywołuje on definicję bliską Spinozie, według której współczucie jest afektywną odpowiedzią „polegającą na uczuciach smutku i zatroskania wobec innego zaniepokojonego lub znajdującego się $\mathrm{w}$ potrzebie osobnika" i dodaje, uzupełniając, że „współczucie oparte jest na zorientowanej na innego altruistycznej motywacji" (De Waal 2013, s. 50). To z kolei oznacza, że współczucie ma podłoże poznawczo-społeczne, zapośredniczone w relacjach z innymi (zapewne w obrębie gatunku i form solidarności międzygatunkowej, co przeczy wulgarnym wykładniom międzygatunkowej konkurencji i bezpardonowej walki o byt). Z kolei tzw. niepokój osobisty miałby skłaniać do samolubnego (a w języku psychologii: egocentrycznego) poszukiwania sposobu na pozbycie się dokładnie tego samego uczucia, jakie trapi obserwowanego osobnika. „Osobisty niepokój nie ma zatem związku z sytuacją, w której znajduje się wzbudzający empatię inny osobnik" (De Waal 2013, s. 51) i jest raczej wyrazem troski o własną kondycję. Analogicznie do zachowań ludzkich, w których empatia i współczucie znajdują wyraz w psychologicznym altruizmie (ujście zaś - w wypływających $\mathrm{z}$ niego działaniach), tak zwierzęta 'uspołecznione' na poziomie afektywnym reagują na emocje innych (ale znów w pewnych granicach, jako, że pożerający antylopę lew musiałby postępować każdorazowo wbrew swojej altruistycznej motywacji, chcąc w ogóle przetrwać - albo też wpaść na pomysł przyłączenia się do antylopy i stołowania na sawannie). Reagowanie na stany emocjonalne innych 
nawiązuje do idei (tzn. możemy próbować je w taki sposób wyjaśniać, albowiem zachowania zwierząt nie nawiązują do żadnych idei) wspólnej reprezentacji mechanizmu percepcji-działania, z perspektywy której empatia stanowi odruchowy, niewolicjonalny i nieintencjonalny proces, manifestujący się $\mathrm{w}$ zautomatyzowanych reakcjach i jako taka, nie wymaga ani inwencji, intencji, ani zdolności sprawstwa (których jednak oczekujemy na gruncie etyki od autonomicznych, czyli wybierających sposób postępowania podmiotów aktów moralnych). Empatia, podsumowuje w swoim nieco redukcjonistycznym modelu źródeł moralności De Waal: „zawiera w sobie całą gamę wzorów związków emocjonalnych, od bardzo prostych i automatycznych po wysoce wyrafinowane" (De Waal 2013, s. 66). Najwyższą formą empatii wyróżnianej przez De Waala jest zdolność atrybucji, oznaczająca pełne przyjęcie cudzej perspektywy $\mathrm{w}$ rozumieniu poznawczym (niekoniecznie $\mathrm{w}$ rozumieniu praktycznym).

W relacji opiekuńczej człowiek przejmuje cudzą perspektywę, powodowany wyborem dobra drugiego, związanego z wewnętrzną wartością jego życia, albo też dobra wspólnego, łączącego ludzkość z żywymi osobnikami należącymi do innych gatunków. Nie zawsze jednak musi przyjmować i rozumieć retorykę opisującą tę relację i współzależność, a nawet taką retorykę tworzyć. Odwołując się do etyki ewolucji wskazywanej przez De Waala, człowiek powinien przyjąć postawę uważną i przytomną, aby mógł jednak wybrać działanie służące żywotnemu interesowi podopiecznego (przyjmując, że zwierzęta również żywią interes życia, co nie dla wszystkich filozofów jest oczywiste) i jednocześnie potrafić przyjmować działania służące jego żywotnemu interesowi ze strony drugich. W konsekwencji oznacza to stałą gotowość do rewizji i modyfikacji własnej postawy, roli i miejsca w świecie, który składa się z relacji między żywymi, zarówno w dobrej, jak i gorszej kondycji: kondycja życia jest bowiem zmienna, i to właśnie ta zmienność wymaga czujności i troski.

\subsection{Eutanazja}

Definicja eutanazji w medycynie weterynaryjnej tym różni się od tej, która wpisuje się w medycynę ludzką (co może brzmieć kontrowersyjnie dla tych, którzy w sposób literalny odczytują Przysięgę Hippokratejską), że obejmuje przypadki zapewnienia dobrej (gr. eu 'dobrze, dobry') śmierci (gr. thanatos) nie tylko $\mathrm{z}$ pobudek litości i miłosierdzia dla innej istoty doznającej nieuśmierzalnych cierpień, ale także $\mathrm{z}$ powodów takich, jak „zapewnienie dobrej śmierci zdrowym zwierzętom dla wygody właściciela, nadmiar zwierząt na danym terytorium, problemy z zachowaniem, lub dawstwo tkanki w celu badań naukowych" (Carbone 1998, s. 164). Najbardziej kontrowersyjny jest tu - w zasadzie fikcyjny w przypadku zwierząt - warunek wyrażenia świadomej, a nawet wielokrotnej świadomej prośby (nie tylko zgody) ze strony umierającego. Okazjonalnie stosowane przez weterynarzy eufemizmy 
związane ze stosowaniem eutanazji u zwierząt również mogą „wprawiać w zakłopotanie albo nieść za sobą szczególne konotacje" (Carbone 1998, s. 164). W szczególności określenie „eutanazja bądź anestezja w znaczeniu usypiania” (Carbone 1998, s. 164) może okazać się mylące dla opiekunów i ich dzieci, utrudniając im zrozumienie znaczenia, intencji i skutków działania weterynarza w stosunku do ich podopiecznych.

Podstawowymi kryteriami doboru technik eutanazyjnych są ból fizyczny (niepoddający się analgezji albo skazujący zwierzę na bardzo silną, długotrwałą lub dożywotnią analgezję, pogarszającą jakość życia i skazującą zwierzę na wegetację), a także ciężki stan psychofizyczny zwierzęcia (jednakże stan fizyczny w diagnostyce kondycji zwierząt ma większe znaczenie od stanu psychicznego; żywotność zwierzęcia jest w tym sensie bardziej wegetatywna i ufizyczniona). Inne kryteria powiadają o „emocjonalnym wpływie na osoby obecne" (Carbone 1998, s. 164) tj. udzielaniu się opiekunom dogłębnego żalu, smutku i rozpaczy, nieznośnych dla nich samych; jednakże w takim przypadku opiekunowie mieliby udział $w$ eutanazji zwierzęcia $\mathrm{z}$ uwagi na jakość ich własnej kondycji, czyli nieznośne i nieuśmierzone współcierpienie $\mathrm{z}$ podopiecznym. Mówią one także o dostępności lub niedostępności odpowiednich „leków oraz zgodności z następującymi badaniami lub wykorzystaniu ciała bądź tkanek zwierzęcia" (Carbone 1998, s. 164). Wytyczne weterynaryjne przewidują i wymieniają listę sposobów i technik przeprowadzania eutanazji, nie zajmują się jednak kwestiami okoliczności, uzasadniania i podejmowania decyzji (zwyczajowo zagadnienia te również w przypadku medycyny ludzkiej podejmują etycy). Zasadność, okoliczności i przebieg poszczególnego zabiegu stanowi wynik indywidualnej praktyki weterynaryjnej:

Mam w zwyczaju - powiada jeden z weterynarzy praktykujących takie zabiegi - pokazywać zwierzęciu pozostającemu przy życiu jego towarzysza, który został poddany eutanazji, kiedy tylko jest to możliwe. Akceptacja sytuacji przez pozostającego przy życiu psa (lub kota) z pewnością zdaje się skracać ich okres żalu lub nerwowe zachowanie (Boden 2005, s. 233).

Przywołane doświadczenie świadczy o tym, że lekarz weterynarii jest przekonany o zdolności rozumiejącej akceptacji przez żywe zwierzę pewnego egzystencjalnego zdarzenia, jakim jest śmierć innego członka jego gatunku czy wspólnoty stada (albo stadła, w którym zwierzęta dotychczas przebywały pod opieką ludzi). To przekonanie jest zaskakująco postępowe $\mathrm{w}$ porównaniu $\mathrm{z}$ niektórymi sporami wśród zawodowych etyków i filozofów, odmawiających zwierzętom rozumienia egzystencjalnej istoty narodzin, cierpienia i śmierci; a przecież rozumienie tak elementarnych doświadczeń może mieć charakter intuicyjny. Również w naturze zwierzęta doświadczają śmierci swoich pobratymców, przeżywają rozłąkę, rozpacz i żałobę, szczególnie dokładnie opisaną na przykładzie prymatów i słoni. 
Doświadczenie utraty ukochanej istoty i rozumienie tego, że jej bezpowrotnie zabrakło, podczas gdy nadal żywy „ja” wraz z innymi muszę sprostać wyzwaniu, jakim jest dalsze trwanie, stanowi istotną część odpowiedzialności opiekuńczej również wśród ludzi obcujących ze zwierzętami. Nie wymaga to antropomorfizacji zwierząt; raczej spojrzenia na ludzkie sprawy z perspektywy żywotności łączącej nas z nimi (o której pisałem przywołując Levinasa). Odpowiedzialność wiąże się z potrzebą namysłu nad „etycznymi i moralnymi dylematami, które są nieuniknione w momentach, gdy emocje biorą górę" (Arden 2003, s. 214), a potrzeba wówczas rozwagi, decyzji i działania: cóż bowiem przyjdzie opiekunowi bądź lekarzowi weterynarii z biernego oglądu i współdoznawanych cierpień? Medycyna, opieka paliatywna, a także eutanazja wymaga aktywnej konfrontacji z niezwykle trudną sytuacją - i wzięcia za nią odpowiedzialności. Trudno jest się nam pogodzić, szczególnie wobec oddanej opieki i troski, z sytuacją, w której wyczerpały się środki działania i opadła nas bezsilność i zwątpienie we własne możliwości radzenia sobie z problemem. Refleksja opiekuna nad cyklem życia i własną rolą w schyłkowym bądź krytycznym jego momencie u podopiecznych jest konieczna i powinna mieć miejsce już na etapie studiów i praktyk lekarskich, zanim dojdzie do rzeczywistej konfrontacji z takimi sytuacjami.

Umiejętność rozpoznawania jakości życia lub jej zaniku u zwierzęcych podopiecznych może w jakiejś mierze ukoić niepokój opiekunów decydujących się na poddanie tych pierwszych eutanazji, nawet, jeśli nie może - i nie powinna - usprawiedliwiać udziału w zakończeniu ich egzystencji: egzystencja i jej atrybuty jakościowe pozostają nadal dwiema różnymi kwestiami, tyle, że w rzeczywistym doświadczeniu i odczuciu żyjącej istoty są one nierozłączne i odbierane jako jedność. Poczucie winy, które dręczy sumienie przy tak doniosłym akcie działania, będzie mniej dojmujące, kiedy uprzednio rozróżni się, iż „eutanazja jest postanowieniem dotyczącym tego, jak zwierzę umrze, nie zaś tego, czy umrze" (Arden 2003, s. 215) - choć to analityczne rozróżnienie, nie jest wcale przekonujące na poziomie intuicyjnym.

Jak już zaznaczono wyżej, warto się w ogóle zastanowić nad tym, czy eutanazja jest właściwym określeniem, skoro relacja ludzkiego decydenta i opiekuna w stosunku do istoty żywej jest relacją istoty wolnej do istoty bezwolnej, nie potrafiącej dokonać takiego wyboru ani nawet wyrazić żadnej o nim opinii. W takim ujęciu eutanazja jawi się raczej jako kontynuacja procesu leczenia, współtworzonego poprzez zaangażowane strony (opiekunów, medyków itd.) na gruncie szacunku dla podmiotowości cierpiącego zwierzęcia, szacunku, który dotyczy życia o znośnej jakości, nie zaś życia za wszelką cenę oraz oddania. Decyzja o łagodnej śmierci dla cierpiącego zwierzęcia nie jest alternatywą dla życia ani w oczach opiekuna, ani - jak można domniemywać podopiecznego, lecz jest częścią cyklu życia. Niezależnie od tego, czy eutanazja jest konsekwencją niewłaściwej lub niedbałej opieki, czy też jest jej kwintesencją wolno przypuszczać, że ból i cierpienia doznawane przez 
podopiecznego nie są możliwe do opanowania dla opiekuna, a przede wszystkim, że stały się nieznośne dla podopiecznego (jako nieopanowane i nie poddające się już kontroli medycznej); zaś perspektywa poprawy komfortu życia jest skutecznie kontaminowana przez rozwój wypadków i nasilenie tego ze wszech miar krytycznego stanu rzeczy, jakim jest nieuleczalna choroba, nieuśmierzone cierpienie, a także nasilające się i niweczące efekt leczniczy skutki uboczne terapii.

\section{Zakończenie}

Istota opieki lekarskiej i lecznictwa ma swe źródło w akcie odseparowania się człowieka od natury i nieuchronności jej praw i procesów, a także w stopniowym zatracaniu naturalnych intuicji w zamian za zdobycze, jakie niesie ze sobą postęp naukowo-techniczny $w$ naukach biomedycznych. Słabnąca wraz z postępem urbanizacji i technicyzacji autonomia człowieka (o której pisałem w tej pracy i którą potwierdzają dodatkowo - dla człowieka - autorzy innej jeszcze pracy (Williams \& Calnan 1996, s. 1609-1620) sprzyja rozwijaniu się uzależnienia najpierw od zwierząt, a obecnie - także od medycyny. Dotyczy to również zwierząt, i to zanim zbudowana została międzygatunkowa relacja opiekuńczo-lecznicza oparta na empatii, która mogłaby oferować obu stronom autonomiczną przestrzeń wzajemnie dopełniających się działań, dóbr i obopólnych korzyści na poziomie jakości życia (chciałbym tu pominąć kategorię interesów, która $w$ tej relacji jednostronnie dominuje od czasów niepamiętnych). Powstanie takiej przestrzeni nie jest możliwe samo przez się, lecz wymaga czynnej inicjatywy ze strony człowieka: wówczas z pewnością nastąpi odpowiedź ze strony zwierząt. Chodzi tu o inicjatywę i inicjację, którą znamionowałyby szacunek, współodczuwanie, rozumienie, miłość, refleksyjność i odpowiedzialność w miejsce dominacji. Istota ludzka kierująca się tak elementarnymi nastawieniami i wartościami jest zdolna otoczyć opieką drugą istotę żywą spoza swojego gatunku, przekraczając tym samym - wcale nie takie sztywne, choć opatrzone licznymi, antropocentrycznymi zasiekami granice 'rozpoznawalności' i 'uznawalności', mówiąc językiem Ricoeura. Te zasieki i granice wyznacza możliwość bądź niemożliwość narracji, interpretacji i odsłaniania znaczeń, które stanowią domenę ludzką. Ale na innej płaszczyźnie - co pokazała już nauka - zachodzi współodczuwanie i towarzyszenie sobie w cierpieniu i lęku przez człowieka i zwierzę: w nim tkwi zaczątek opiekuńczo-terapeutycznej relacji, w której sfera językowo-symboliczna nie dominuje. Współczucie - a nie racjonalna kalkulacja korzyści - otwiera na etyczną percepcję doświadczeń, jakie mają inne gatunki, uwięzione tylko, ale tak naprawdę przynależne innej rzeczywistości: nazywa się ona dzikością i ludzkość nie może jej zawłaszczyć. Świat natury i świat życia nie jest w taki sposób uporządkowany, choć jest w dużej mierze skolonizowany przez ludzką racjonalność. Czy ona czyni go 
lepszym? Z pewnością nie. Lepszym czyniłby go rozum, który jest czymś innym aniżeli racjonalność. Nie należy przy tym traktować współczucia jako zamiennika rozumu, lecz jako jego uzupełnienie, umożliwiające rozumną, tj. adekwatną reakcję na rozpoznany i zdiagnozowany ból, doznawany przez istoty żywe. Współdziałanie różnych sposobów percepcji, poznania i uznania może przynieść istotom żywym, powszechną korzyść. Jeśli miałyby one obejmować również weterynaryjną opiekę paliatywną, to właśnie to starałem się $\mathrm{w}$ tej pracy pokazać, eksponując połączenie pierwiastka rozumności i empatycznego w praktyce medycznej, której powodzenie jest udziałem zarówno podopiecznych, jak i opiekunów, przez co wpisuje się w etykę troski i etykę zawodową, etykę nauki i etykę konsumpcji, którą człowiek żyjący w takim właśnie świecie powinien po prostu zrewidować.

\section{Literatura}

Altez-Albela, F. R. 2012. "The Body and Transcendence in Emmanuel Levinas' Phenomenological Ethics." Kritike, Vol. 5, No. 1: 36-50.

Arden, D. 2003. Book of Wellness and Preventive Care for Dogs. P. C. Gambardella (ed.). E-book Series, McGraw-Hill.

Bernstein, M. H. 2004. Without a Fear: Our Tragic Relationship with Animals. Board of Trustees of the University of Illinois.

Boden, E. (ed.) 2005. Black's Veterinary Dictionary, 21 ${ }^{\text {st }}$ edition. London: A\&C Black Publishers Ltd.

Carbone, L. 1998. "Euthanasia." W: Bekoff, M. \& C. A. Meanney (eds.) Encyclopedia of Animal Rights and Animal Welfare (pp. 164-166). Westport: Greenwood Press.

Cavalieri, P. 2006. "The Animal Debate: A Reexamination". W: P. Singer (ed.) In Defense of Animals: The Second Wave (pp. 54-68). Oxford: Blackwell Publishing.

Darwin, Ch. 2009. O pochodzeniu człowieka. Tł. M. Ilecki. Warszawa: Jirafa Roja.

Davis, R. G. (ed.) 2011. Caring for Family Pets: Choosing and Keeping Our Companion Animals Healthy. Santa Barbara: Praeger.

Dawkins, S. M. 2006. "The Scientific Basis for Assessing Suffering in Animals." W: P. Singer (ed.) In Defense of Animals: The Second Wave (pp. 26-39). Oxford: Blackwell Publishing.

Day By Day. 2016. “Terminal Illness: Receiving a terminal diagnosis.” Day By Day Pet Caregiver Support. URL: http://www.daybydaypetsupport.com/terminal-cancer-receving/ (retrieved on: 02.12.2015.)

DeGrazia, D. 2006. "On the Question of Personhood Beyond Homo Sapiens." W: P. Singer (ed.) In Defense of Animals: The Second Wave (pp. 40-53). Oxford: Blackwell Publishing. 
De Waal, F. 2013. Małpy i filozofowie. Tł. B. Brożek \& M. Furman. Kraków: Copernicus Center Press.

Dłużewicz, A. 2014. "Etyka utylitarystyczna Petera Singera - szanse i możliwości przekształcenia praw zwierząt". Ethics in Progress, Vol. 5(1): 124-136. doi: 10.14746/eip.2014.1.11.

Eldredge, D. M. et al. 2008. "Cat Owner's Home Veterinary Handbook", $3^{\text {rd }}$ edition. B. Adelman (ed.). Hoboken NJ: Wiley Publishing, Inc.

Fallon, M. \& G. Blanks (eds.) 2006. ABC of Palliative Care, $2^{\text {nd }}$ edition. Oxford: Blackwell Publishing.

Gaverick, M. 2006. "Utilitarianism and Animals." W: P. Singer (ed.) In Defense of Animals: The Second Wave (pp. 13-25). Oxford: Blackwell Publishing.

Gaynor, J. 2008. "Control of Cancer Pain in Veterinary Patients." Veterinary Clinics of North America: Small Animal Practice, Vol. 38(6): 1429-1448.

Górecki, M. 1999. "Chory terminalnie i jego rodzina". Ruch Prawniczy, Ekonomiczny i Socjologiczny, rocznik LXI(1): 263- 278.

Grandin, T. \& C. Johnson. 2011. Zwierzęta czyniq nas ludźmi. Tł. K. Puławski. Poznań: Wydawnictwo Media Rodzina.

Hanna, R. \& E. Thompson 2012. "Problem umysł-ciało-ciało". Tł. P. Nowakowski. Avant, III(T): 14-37.

Heinrich, B. 2014. Wieczne życie. O zwierzęcej formie śmierci. Tł. M. Szczubiałka. Wołowiec: Wydawnictwo Czarne.

IASP. 1994. „Pain.” IASP Taxonomy. URL: http://www.iasppain.org/Taxonomy\#Pain (retrieved on: 15.12.2015.)

Jan Paweł II. 2003. Encykliki Ojca Świętego Jana Pawła II. Kraków: Wydawnictwo Znak.

Johns, C. 2004. Being Mindful, Easing Suffering: Reflections on Palliative Care. London: Jessica Kingsley Publishers.

Kemmerer, L. 2006. "In Search of Consistency: Ethics and Animals." K. Shapiro (ed.). Leiden: Koninklijke Brill NV.

Kirkwood, J. \& R. Hubrecht (eds.) 2010. The UFAW Handbook on the Care and Management of Laboratory and Other Research Animals, $8^{\text {th }}$ edition. Universities Federation for Animal Welfare.

Kowalczyk, M. 2012. "Opieka paliatywna jako jedna z form opieki nad pacjentem terminalnie chorym". Państwo i Społeczeństwo, XII(2): 7482.

Kropikiewicz, H. 2011. Biokomunikacja. Jak zwierzęta porozumiewajq̨ się ze światem. Poznań: Wydawnictwo Naukowe UAM.

Kübler-Ross, E. 1998. Rozmowy o śmierci i umieraniu. Tł. I. Doleżal-Nowicka. Poznań: Media Rodzina.

Latham, N. 2010. "Brief Introduction to Welfare Assessment: A 'Toolbox' of Techniques." W: Kirkwood, J. \& R. Hubrecht (eds.) The UFAW Handbook 
on the Care and Management of Laboratory and Other Research Animals. Wheathampstead, Herts: UFAW.

Nagel, T. 1997. Pytania ostateczne. Tł. A. Romaniuk. Warszawa: Aletheia.

Norkus, C. 2012. Veterinary Technician's Manual for Small Animal Emergency and Critical Care. Chichester, West Sussex: Wiley-Blackwell.

OED. 2016. "Charity." Online Etymology Dictionary. URL: http://www.etymonline.com/index.php?term=charity\&allowed_in_fram $\mathrm{e}=0$ (dostęp: 02.12.2015).

Pasieka, P. 2012. "Kartezjańska koncepcja zwierzęcia - maszyny". Filo-Sofija, Vol 17(2): 51-64.

Pinney, C. 2004. The Complete Home Veterinary Guide, $3^{\text {rd }}$ edition, e-book, McGraw-Hill.

Ricoeur, P. 2004. Drogi rozpoznania. Tł. J. Margański. Kraków:: Wydawnictwo Znak.

Rollin, E. B. 2011. Putting the Horse Before Descartes. My Life's Work on Behalf of Animals. Philadelphia: Temple University Press.

Roper, K. 2013. "Warning Signs a Dog Is Dying." LoveToKnow. URL: http://dogs.lovetoknow.com/wiki/Warning_Signs_a_Dog_Is_Dying (dostęp: 05.12.2015.)

Sager, J. K. 2012. "Anesthesia and Analgesia." W: C. Norku (ed.) Veterinary Technician's Manual for Small Animal Emergency and Critical Care (pp. 465-493). West Sussex, Chichester: Wiley-Blackwell.

Singer, P. (ed.) 2006. In Defense of Animals: The Second Wave. Oxford: Blackwell Publishing Ltd.

Swabe, J. 2005. Human-Animal Relations and the Rise of Veterinary Medicine. Taylor \& Francis, e-Library.

Thoreau, H. D. 1991. Walden. Tł. H. Cieplińska. Warszawa: Państwowy Instytut Wydawniczy.

Waldau, P. 2006. "Religion and Animals." W: P. Singer (ed.) In Defense of Animals: The Second Wave (pp. 69-83). Oxford: Blackwell Publishing.

WHO. 2004. "WHO Definition of Palliative Care". World Health Organization. URL: http://www.who.int/cancer/palliative/definition/en/ (dostęp: 30.04.2016.)

Williams, S. \& Calnan, M. 1996. "The 'Limits' of Medicalization? Modern Medicine and the Lay Populace in 'Late' Modernity." Social Science \& Medicine, Vol 42(12): 1609-1620.

Źrodła prawne: Dz.U. 1997 nr 111. 
Krzysztof Kuśnierz

(Adam Mickiewicz University in Poznań, kristofka@vp.pl)

\title{
Imperative to Palliative Care in Veterinary Medicine
}

\begin{abstract}
One of the main causes of the ethical ambivalence in the attitude of homo sapiens species towards other living creatures is its utilitarian and anthropocentric mindset which permeates practical decisions and judgments. Socio-ecological conditioning of the human-animal relations to which the former contributed through practices and habits (habitus) largely designating
\end{abstract}


the so called cultural norms (at least in Bourdieu's conception) have thus far legitimized speciesism as well as disablement and exclusion of animals from the advantages of technology and veterinary medicine, which in turn would strengthen their position in the face of continual exploitation in favor of man. Snce few decades this state of affairs has been changing; man's ethical consciousness in respect of the predicament, state of mind and well-being of other living creatures is rising. The encounter of man with different nonhuman beings who do not know human forms of auto-expression or communication became possible through the discovery of science - as well as philosophy's and particularly ethics' indication - of common properties and socio-cognitive capabilities: including fellow feeling which in case of a human being is followed by consciousness, understanding, interpretation, as well as relevant decisions and actions. This common denominator among species is waiting for further exploration and redefinition in terms of ethics. That is exactly what constitutes the requirement for improvement of the condition of other species in the world exploited by human kind. Many academic disciplines contribute to the unceasing widening of the moral horizon (empathy, fellow feeling, responsibility, solidarity, readiness to care and help) so that it could embrace over time as many individuals representing species outside homo sapiens as possible. Veterinary medicine and palliative care create conditions that foster the rebuilding of a caring relationship between man and other living creatures, opening at the same time door to recognition and meaningful relations (in Ricoeur's terms), understanding and love of the universe of life (bios) that man shares with other species.

Keywords: anthropocentrism, speciesism, universe of life, empathy, fellow feeling, recognition, state of mind, veterinary palliative care

Ethics in Progress (ISSN 2084-9257). Vol. 7 (2016). No. 1, Art. \#7, pp. 67-102.

doi: 10.14746/eip.2016.1.5 